\title{
Are Xenotransplantation SAFEguARDS LEGALLY VIABLE?
}

\author{
By Patrik S. Florencio' and Erik D. Ramanathant
}

\begin{abstract}
Scientists agree on the need for robust public health safeguards to accompany the imminent introduction of xenotransplantation-clinical transplantation of animal tissues into humans. To protect society in the event of emerging infectious diseases, governments must devise a legally effective means of ensuring compliance with such safeguards.

Neither consent law, the law of contracts, nor existing public health legislation can adequately enforce such compliance. Consent law serves as a mechanism of communicating the momentary waiver of legal rights, not as a durable enforcement doctrine. Because it would be essential for recipients personally to comply with public safety measures, the law of contracts would also be unable to compel compliance. Existing public health legislation would also likely be ineffective because it would need to be substantially amended to incorporate the heightened powers necessary for the periodic examination of asymptomatic xenotransplant recipients.

Xenotransplantation-specific legislation would be a legally effective means of enforcing public health safeguards since it could require conforming behaviors and could impose monetary fines on those recipients who, having benefited from life-saving intervention, fail to comply. This Article argues that legislation implementing a post-xenotransplantation surveillance system should withstand constitutional scrutiny because it would not be discriminatory and because, although it would violate fundamental rights of recipients, such violations would be justified under existing constitutional doctrines.
\end{abstract}

\footnotetext{
(C) 2001 Patrik S. Florencio and Erik D. Ramanathan.

Associate, Proskauer Rose LLP, New York; LL.B., B.C.L., McGill Law School; B.Sc., McGill University. Contact (212) 969-3000 or pflorencio@ proskauer.com.

¥ Director, Legal Department, ImClone Systems Inc., New York; J.D., Harvard Law School; B.A., The Johns Hopkins University. Contact (212) 645-1405 or erikr@imclone.com.
} 


\section{TABLE OF CONTENTS}

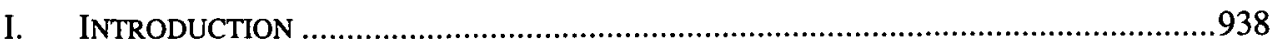

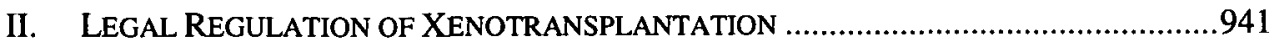

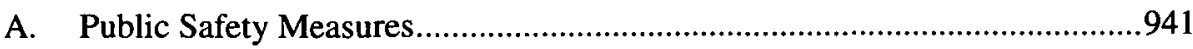

1. The Need for Public Safety Measures...................................................941

2. Proposed Public Safety Measures in the Case of Xenotransplantation..945

B. Enforcing Public Safety Measures..................................................................947

1. From Informed Consent to Binding Contract?.....................................948

a) Informed Consent is Not a Promise to Undertake Future Obligations....................................................................................948

b) Contract Law Is Not a Viable Enforcement Mechanism .................949

2. Current Public Health Legislation

a) Current Public Health Legislation is Designed to Curb the Spread of Infectious Disease by Authorizing Examination of Individuals and Penalties for Non-compliance.

b) Current Public Health Legislation is Nevertheless Incapable of Adequately Regulating Xenotransplantation

3. Proposal for New Xenotransplantation Legislation ..............................960

III. CONSTITUTIONAL DIMENSION: BalanCING THE RIGHTS OF THE COLleCtive and THE DUTY of the STATE to Protect the PUBlic Health WITH the

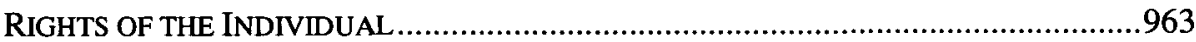

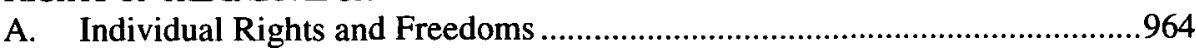

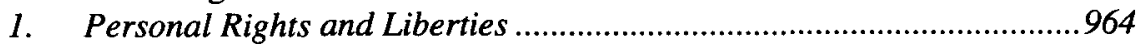

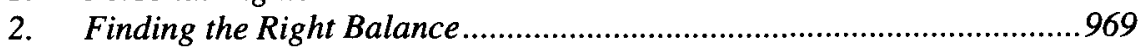

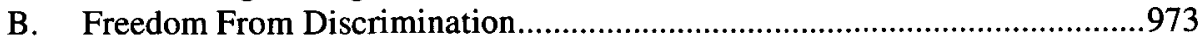

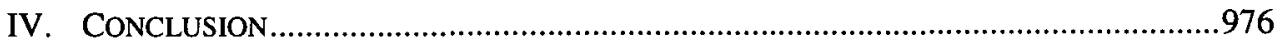

\section{INTRODUCTION}

Xenotransplantation is an innovative medical procedure in which materials such as cells, tissues, or organs are procured from animal sources and subsequently transplanted into humans. Scientists have already managed successfully to transplant animal cells and tissues into humans; ${ }^{1}$ all attempts at animal-to-human whole organ transplantation, however, have failed because of immunological rejection. ${ }^{2}$ Nonetheless, scientists have

1. Terrence Deacon et al., Histological Evidence of Fetal Pig Neural Cell Survival After Transplantation into a Patient with Parkinson's Disease, 3 NATURE MED. 350 (1997); C.G. Groth et al., Transplantation of Porcine Fetal Pancreas to Diabetic Patients, 344 LANCET 1402 (1994); Ole Isacson \& Xandra O. Breakefield, Benefits and Risks of Hosting Animal Cells in the Human Brain, 3 NATURE MED. 964 (1997); Rachel Nowak, Xenotransplants Set to Resume, 266 SCI. 1148 (1994); Joseph Palca, Animal Organs for Human Patients?, 25 HASTINGS CENT. REP. 4 (1995).

2. Leonard L. Bailey et al., Baboon-to-Human Cardiac Xenotransplantation in a Neonate, 254 JAMA 3321 (1985); Keith Reemtsma, Renal Heterotransplantation from Non-Human Primate to Man, 162 ANNALS. N.Y. ACAD. SCI. 412 (1969); T.E. Starzl et 
recently achieved significant experimental progress in overcoming the immunological and physiological barriers to whole organ xenotransplantations, and expect this biotechnology to become a clinical reality in the near future. ${ }^{3}$

By offering a potentially limitless source of animal materials for transplantation, ${ }^{4}$ xenotransplantation biotechnology-or xenobiotechnology for short-promises substantial future medical benefits, and may put an end to the current worldwide shortage of replacement organs. ${ }^{5}$ Yet xenobiotechnology also carries with it a serious risk of introducing and spreading new infectious diseases into the world's human population. ${ }^{6}$ Specifically, infectious animal agents residing in the source material could infect the xenotransplant recipient who could then pass this infection on to the community, causing morbidity and mortality if pathogenic. There is, consequently, a foreseeable yet unquantifiable possibility that xenobiotechnology might give rise to a human epidemic with effects comparable to those of HIV/AIDS or worse. ${ }^{7}$

In light of these foreseeable risks of harm, some commentators have advocated a precautionary approach to clinical xenotransplantation on the basis that a number of scientific, ethical, legal, and public health issues need to be addressed before proceeding with xenobiotechnology. ${ }^{8}$ In con-

al., Baboon-to-Human Liver Transplantation, 341 LANCET 65 (1993); T.E. Starzl et al., Renal Heterotransplantation from Baboon to Man: Experience with Six Cases, 2 TRANSPLANTATION 752 (1964).

3. Jeffrey L. Platt, New Directions for Organ Transplantation, 392 NATURE 11 (1998); Thomas E. Starzl et al., Will Xenotransplantation Ever Be Feasible?, 186 J. AM. C. SURGEONS 383 (1998).

4. Robert P. Lanza et al., Xenotransplantation, 277 SCI. AM. 54 (1997).

5. According to recent Canadian statistics, the shortage of human donor organs is such that each year only $16 \%$ of Canadians waiting to receive a heart transplant and $2.7 \%$ of Canadians waiting for a kidney transplant actually obtain one. Comparable statistics apply to potential liver and lung transplant patients. See The Canadian Organ Replacement Register Annual Report: Organ Donation and Transplantation, 2 CANADIAN INST. FOR HEALTH INFO. (1997).

6. Jonathan S. Allan, Xenotransplantation at a Crossroads: Prevention Versus Progress, 2 NATURE MED. 18 (1996); Louisa E. Chapman et al., Xenotransplantation and Xenogeneic Infections, 333 NEW ENG. J. MED. 1498 (1995); Jay A. Fishman, The Risk of Infection in Xenotransplantation, 862 ANNALS N.Y. ACAD. SCI. 45 (1998); Clive Patience et al., Zoonosis in Xenotransplantation, 10 CURRENT OPINION IMMUNOLOGY 539 (1998); Robin A. Weiss, Transgenic Pigs and Virus Adaptation, 391 NATURE 327 (1998).

7. Id. For a good summary of the risks and benefits associated with xenotransplantation, see Declan Butler et al., Last Chance to Stop and Think on Risks of Xenotransplantation, 391 NATURE 320 (1998).

8. See, e.g., Jonathan S. Allan, Nonhuman Primates as Organ Donors?, 77 BULL. WORLD HEALTH ORG. 62 (1999); F.H. Bach et al., Uncertainty in Xenotransplantation: 
trast, other commentators have stressed that progress should not be impeded, as the potential benefits to patients could be great and the associated risk to the community remains unquantifiable. ${ }^{9}$ Given the recent international flurry of activity preparing for the arrival of xenotransplantation, the latter view seems to be prevailing. ${ }^{10}$

The critical question no longer revolves around whether we have the scientific knowledge and ability to introduce clinical xenotransplantation, but is instead directed at the circumstances under which it would be acceptable to proceed. Importantly, despite the divergence of opinion as to whether further scientific, ethical, and legal analyses are required prior to introducing clinical xenotransplantation, everyone has agreed that should xenotransplantation proceed in the near future, the government must also implement robust public safety measures. ${ }^{11}$ The debate now encompasses an important legal component: to what extent, if at all, will the law be capable of enforcing those public health safeguards that the scientific community deems necessary?

This Article will argue that the legal authority to enforce the most important public health safeguard associated with post-xenotransplantation surveillance-the periodic collection of bodily specimens such as serum samples from xenotransplant recipients-could exist, but that its subsistence would ultimately depend on its ability to withstand constitutional challenges. Although the medical community could not physically compel

Individual Benefit Versus Collective Risk, 4 NATURE MED. 141 (1998); Patrik S. Florencio \& Timothy Caulfield, Xenotransplantation and Public Health: Identifying the Legal Issues, 90 CAN. J. PUB. HEALTH 282 (1999); Jonathan Hughes, Xenografting: Ethical Issues, 24 J. MED. ETHICS 18 (1998).

9. See, e.g., David H. Sachs et al., Xenotransplantation-Caution, But No Moratorium, 4 NATURE MED. 372 (1998); Daniel R. Salomon et al., Xenotransplants: Proceed with Caution, 392 NATURE 11 (1998); Thomas E. Starzl et al., Will Xenotransplantation Ever Be Feasible?, 186 J. AM. C. SURGEONS 383 (1998).

10. See, e.g., Xavier Bosch, Spanish Researchers Reject Xeno Moratorium While Canada Faces the Issue Head-On, 5 NATURE MED. 361 (1999); Declan Butler, US Decides Close Tabs Must Be Kept on Xenotransplants and Sets Up a Body To Oversee Trials, 405 NATURE 606 (2000); Rebecca Currie, UK Moves Ahead on the Xenotransplantation Issue, 4 NATURE MED. 988 (1998); Gretchen Vogel, No Moratorium on Clinical Trials, 279 SCI. 648 (1998). But see Declan Butler, Europe is Urged to Hold Back on Xenotransplant Clinical Trials, 397 NATURE 281 (1999).

11. See generally supra notes 6,8 and 9. See also L.E. Chapman et al., Xenotransplantation: The Potential for Xenogeneic Infections, 31 TRANSPLANTATION PROC. 909 (1999); Jay A. Fishman, Infection and Xenotransplantation: Developing Strategies to Minimize Risk, 862 ANNALS N.Y. ACAD. SCI. 52 (1998); Frederick A. Murphy, The Public Health Risk of Animal Organ and Tissue Transplantation into Humans, 273 SCI. 746 (1996); Robin A. Weiss, Xenografts and Retroviruses, 285 SCI. 1221 (1999). 
recipients to provide serum samples, the government could enact legislation to fine recipients who, having benefited from the life saving intervention, refused to accept responsibility for conforming to the public safety measures.

This Article begins by explaining why the scientific community agrees that xenotransplantation requires robust public safety measures. The Article will demonstrate that the importance of the safeguards lies not in their ability to prevent the emergence of infectious diseases-because they are incapable of doing so- but in their ability to provide the foundation for a rapid response to emerging infectious diseases. The Article then summarizes the nature and scope of the public safety measures proposed by the health authorities in the various countries now contemplating the introduction of clinical xenotransplantation.

The Article goes on to examine the various sources of legal authority that authorities might use to enforce compliance with the safeguards. In this discussion, the Article focuses on the laws of both the United States and Canada for two reasons. First, a comparative review of their laws allows one to draw upon the best practices of two legal traditions in analyzing existing and proposed legal safeguards. Second, the public health systems of these neighboring nations are inextricably intertwined and, although they cannot insulate themselves from the world's public health crises in an age of global travel and migration, coordination of multinational public health efforts would be an excellent start to addressing the problem globally. The final section of the Article comments on the constitutional dimension of the problem in both countries. The Article concludes that restrictions on the rights of recipients that would necessarily result from the enactment of xenotransplantation legislation would be in accordance with the principles of fundamental justice and would thus be demonstrably justified in a free and democratic society.

\section{LEGAL REGULATION OF XENOTRANSPLANTATION}

\section{A. Public Safety Measures}

\section{The Need for Public Safety Measures}

It is probably fair to state that we are not yet, nor are we likely to become in the near future, masters of the microbial world. ${ }^{12}$ Even though

12. The microbial world is thought by many to pose one of the biggest threats to the future existence of humankind:

Ingenuity, knowledge, and organization alter but cannot cancel humanity's vulnerability to invasion by parasitic forms of life. Infectious dis- 
infectious diseases have always plagued humans, our science is still young and has not yet matured to a level where it might be acceptable to ignore the potential harms that infectious diseases can cause. One need only to look at the devastation wrought by the periodic emergence of yellow fever in European and American cities during the eighteenth and nineteenth centuries to see the damage that infectious disease can cause. ${ }^{13}$ Recent examples, such as the 1995 epidemic of Ebola hemorrhagic fever in the Democratic Republic of Congo, demonstrate that our vulnerability to infectious diseases is not a historical relic. ${ }^{14}$ The resurgence of diseases such as tuberculosis ${ }^{15}$ and the spread of HIV ${ }^{16}$ remind us that infectious illnesses can also have a dramatic impact on the modern western world. Today, infectious diseases are the third leading cause of death in the United States, and the leading cause worldwide. ${ }^{17}$

It is because of our physiological vulnerability to infectious microbes that we must proceed prudently and conscientiously when engaging in activities that raise the specter of emerging infectious illnesses, especially when the etiology of disease is our own behavior. Indeed, human behavior

ease which antedated the emergence of humankind and will last as long as humanity itself, and will surely remain, as it has been hitherto, one of the fundamental parameters and determinants of human history.

William H. MCNeIll, Plagues and PeOPles 291 (1976). See also Joshua Lederberg, Medical Science, Infectious Diseases, and the Unity of Humankind, 260 JAMA 684 (1988).

13. For instance, the yellow fever epidemic that hit Memphis in 1878 is recorded to have led to the death of a quarter of its population. J.M. KEATING, HISTORY OF THE YELLOW FEVER EPIDEMIC OF 1878 IN MEMPHIS, TENNESSEE 116 (Cincinnati, Wrightson \& Co. 1879).

14. Barbara Kerstiëns \& Francine Matthys, Interventions to Control Virus Transmission during an Outbreak of Ebola Hemorrhagic Fever: Experience from Kikwit, Democratic Republic of the Congo, 1995, 179 J. INFECTIOUS DISEASES 263 (Supp. 1999). See also MichaEl B.A. OldSTONE, VIRUSES, PlAGUES, AND HISTORY 130-35 (1998).

15. Christopher Dye et al., Global Burden of Tuberculosis: Estimated Incidence, Prevalence, and Mortality by Country, 282 JAMA 677 (1999); Thomas R. Frieden et al., The Emergence of Drug-Resistant Tuberculosis in New York City, 328 NEW ENG. J. MED. 52 (1993).

16. Jonathan M. Mann \& Daniel J.M. Tarantola, HIV 1998: The Global Picture, 279 SCI. AM. 82, 82 (1998) ("Since the early 1980s more than 40 million individuals have contracted HIV, and almost 12 million have died . . . In 1997 alone, nearly six million people-close to 16,000 a day-acquired HIV, and some 2.3 million perished from it, including 460,000 children.").

17. Gregory L. Armstrong et al., Trends in Infectious Disease Mortality in the United States During the 20th Century, 281 JAMA 61 (1999); Sue Binder et al., Emerging Infectious Diseases: Public Health Issues for the 21st Century, 284 SCI. 1311 (1999); Robert W. Pinner et al., Trends in Infectious Diseases Mortality in the United States, 275 JAMA 189 (1996). 
is the leading cause of emerging infectious diseases. ${ }^{18}$ For example, the immense volume of global travel has made us more vulnerable to the effects of infectious diseases today than we have ever been in the past. ${ }^{19}$ If we are not careful, xenotransplantation could become the next example of human behavior that results in the introduction of new infectious microbes into the human population. ${ }^{20}$

The foregoing commentary means to provide the reader with an awareness of why the scientific community agrees that robust public safety measures must accompany the introduction of xenotransplantation. The following passage embodies the quintessence of this commentary: "[h]istory has shown us repeatedly, in terms of both human suffering and economic loss, that the costs of preparedness through vigilance are far lower than those needed to respond to unanticipated public health crises." ${ }^{21}$ In the context of xenotransplantation, preparedness means public health safeguards.

18. David M. Forrest, Control of Imported Communicable Diseases: Preparation and Response, 87 CAN. J. PUB. HEALTH 368, 368-69 (1996):

A number of factors, both singly and interactively, facilitate the emergence of new diseases. These include environmental and geoclimatic conditions, fluctuating reservoir and vector characteristics, microbial conditions, and especially, human factors. Human factors include anthropogenic ecological change, alterations in demographics and behaviours, international travel and commerce, and deficiencies in public health structure.

See also Stephen S. Morse \& Ann Schluederberg, Emerging Viruses: The Evolution of Viruses and Viral Diseases, 162 J. INFECTIOUS DISEASES 7 (1990).

19. Stephen S. Morse, Factors in the Emergence of Infectious Diseases, 1 EMERGING INFECTIOUS DISEASES 1, 10 (1995).

The history of infectious diseases has been a history of microbes on the march, often in our wake, and of microbes that have taken advantage of the rich opportunities offered them to thrive, prosper, and spread. And yet the historical processes that have given rise to the emergence of new infections throughout history continue today with unabated force; in fact, they are accelerating, because the conditions of modern life ensure that the factors responsible for disease emergence are more prevalent than ever before.

See generally MARY E. WILSON, A WORLD GUIDE TO INFECTIONS: DISEASES, DisTRIBUTION, DIAGNOSIS (1991).

20. Patrik S. Florencio \& Nathalie Weizmann, Xenotransplantation and the Role of Human Behaviour in the Emergence of Infectious Disease, 7 HEALTH L. REV. 20 (1998).

21. Ruth L. Berkelman et al., Infectious Disease Surveillance: A Crumbling Foundation, 264 SCI. 368, 370 (1994). 
Public safety measures would establish a surveillance system ${ }^{22}$ that should permit the early detection of-and a rapid response to-any emerging epidemics. ${ }^{23}$ Commentators have often described surveillance as the cornerstone of infectious disease control, ${ }^{24}$ and as "essential to minimize illness, disability, death, and economic losses." ${ }^{25}$ However, it must be made absolutely clear that any surveillance system would be incapable of preventing the emergence of infectious illnesses. As one group of commentators stated: "surveillance is not the same as prevention. New infectious agents may spread and cause disease among human populations before surveillance techniques have permitted their detection and isolation. Further, detection and isolation of infectious agents does not equate to the containment of their propagation at the human level.,"26

The importance of surveillance is problematic, because, in general, our public health infrastructure is "geared to crisis response, but seems inadequately prepared for proaction, crisis anticipation, and prevention." ${ }^{27}$ Prevention means avoiding a public health crisis through instrumentalities such as vaccines and, in the case of xenotransplantation, the imposition of a moratorium until we know more about the associated infectious disease risks. As noted above, however, the current international trend has been to reject the precautionary approach and to prepare for the arrival of clinical xenotransplantation. Further, even if governments implement preventative measures, infectious microbes could still emerge from xenotransplantation and could result in severe morbidity and mortality if pathogenic in human populations. Appropriate safeguards would nevertheless represent an essential precaution to such consequences, as they would ideally enable offi-

22. The United Kingdom Xenotransplantation Interim Regulatory Authority (UKXIRA), the regulatory authority in charge of overseeing xenobiotechnology in England, defines surveillance as the "on-going systematic collection, analysis, and interpretation of relevant data, closely integrated with the timely dissemination of these data to those responsible for control and prevention" and state that surveillance is a "critical step in the pathway of identification and prevention of infectious diseases and xenogeneic infections." See U.K. XenOtRansPlantation Interim Regulatory Auth., Draft REPORT OF THE INFECTION SURVEILLANCE STEERING GROUP OF THE UKXIRA 6, 17 (May 1999), at http://www.doh.gov.uk/pub/docs/doh/surveil.pdf [hereinafter UKXIRA].

23. James M. Hughes \& John R. La Montagne, Emerging Infectious Diseases $170 \mathrm{~J}$. INFECTIOUS DISEASES 263 (1994).

24. Donald A. Henderson, Surveillance Systems and Intergovernmental Cooperation, in EMERGING VIRUSES 283 (Stephen S. Morse ed., 1993). See also Ruth L. Berkelman \& James M. Hughes, The Conquest of Infectious Diseases: Who Are We Kidding? 119 ANNALS INTERNAL MED. 426 (1993).

25. Binder et al., supra note 17, at 1311.

26. Florencio \& Caulfield, supra note 8, at 283-84.

27. Forrest, supra note 18 , at 368 . 
cials to respond quickly to emerging infectious diseases through the rapid detection and isolation of the microbes responsible for causing sickness and the subsequent development of treatments.

\section{Proposed Public Safety Measures in the Case of Xenotransplantation}

Recognizing the need for public safety measures to accompany the clinical introduction of xenotransplantation, the health departments of various governments-including those of the United States, ${ }^{28}$ the United Kingdom, ${ }^{29}$ and $\mathrm{Canada}^{30}$-have drafted guidelines proposing public health safeguards that are intended to form the foundation of infectious disease surveillance. Although each country's guidelines differ in many respects, each imposes similar requirements on xenotransplant recipients. In light of this similarity, and to avoid repetition, this Article will use the recently drafted guidelines from the United Kingdom to exemplify the nature of the safeguards proposed in all three jurisdictions. ${ }^{31}$

According to the United Kingdom's guidelines, its surveillance system intends to enable the prompt recognition, investigation and management of infectious illnesses that might emerge as a result of xenobiotechnology. ${ }^{32}$ In order to have access to clinical xenotransplantation, recipients would need to agree to: 1) the periodic provision of bodily samples that would then be archived for epidemiological purposes; ${ }^{33}$ 2) post-mortem analysis in case of death, the storage of samples post-mortem, and the disclosure of this agreement to their family; 3) refrain from donating blood, tissue or organs; 4) the use of barrier contraception when engaging in sexual intercourse; 5) keep both name and current address on register and to notify the

28. See U.S. DEP'T OF HEALTH AND HuMAN SERVS., PHS GUIDELINE ON INFECTIOUS DISEASE ISSUES IN XENOTRANSPLANTATION, at http://www.fda.gov/cber/ gdlns/xenophs0101.pdf (January 19, 2001) [hereinafter U.S. DEP'T OF HEALTH AND HUMAN SERVS.].

29. See UKXIRA, supra note 22.

30. See Health Canada, Proposed Canadian Standard for XenotransplanTATION, at http://www.hc-sc.gc.ca/hpb-dgps/therapeut/zfiles/english/btox/standards/ xeno_std_e.html (July 1999) [hereinafter HEALTH CANADA].

31. Although we have chosen to focus on American and Canadian law in this Article, we believe that the xenotransplantation guidelines issued by the United Kingdom are the most comprehensive to date, and are therefore the best model for the discussion of Western governments' preliminary thinking about xenotransplantation safeguards.

32. See UKXIRA, supra note 22 , at 8 .

33. Id. at 29. The guidelines, which are subject to review on the basis of emerging scientific information, call for baseline sampling pre-xenotransplantation and for sampling at 0-2 days; 2, 4 and 6 weeks; 3 and 6 months; 1 and 2 years postxenotransplantation. 
relevant health authorities when moving abroad; and 6) divulge confidential information, including one's status as a xenotransplant recipient, to researchers, all health care professionals from whom one seeks professional services, and close contacts such as current and future sexual partners. ${ }^{34}$ The recipient would have to adhere to these obligations consistently for the recipient's lifetime, or until the government determines that there is no longer a need for public health safeguards. ${ }^{35}$

By far the most important of these public health safeguards, and the only safeguard that will be receiving attention throughout this article, is the collection and archiving of bodily specimens that are needed for epidemiological purposes. Regarding this essential safeguard, the United Kingdom's guidelines state that:

Surveillance of potential xenogeneic infections in humans requires access to human and animal data .... Effective public health response to an incident [of infectious disease] is dependent on both maintenance of records and of archived specimens both at the time of xenotransplantation and for the future. Animal and human specimens need to be held for public purposes. Access by the relevant authorities to appropriate information and samples from locally held records and archives must be a precondition to approval for a clinical trial. ${ }^{36}$

Even outside of the context of xenobiotechnology, scientists have been calling for "well-controlled epidemiology, careful clinical and histologic observations, and increased attention to specimen collection and processing." 37 Without the enforcement of this safeguard in connection with

34. Id. at $29-30$.

35. Id. at 11,21 .

36. Id. at 10-13 (emphasis added). Similarly, the Canadian guidelines stipulate that the "patient will need to comply with long term surveillance necessitating routine physical evaluations with archiving of tissues and/or serum specimens from the recipient" and that "[c]onsent should indicate that the patient is obligated to follow all of the requirements of the program." HeALTH CANADA, supra note 30 (emphasis added). Moreover, the United States guidelines state for example that "[p]ost-xenotransplantation clinical and laboratory surveillance of xenotransplantation recipients is critical, as it provides the means of monitoring for any introduction and propagation of xenogeneic infectious agents in the xenotransplantation product recipient." DEP'T OF HEALTH AND HUMAN SERVS., supra note 28, at 35 (emphasis added).

37. David A. Relman, The Search for Unrecognized Pathogens, 284 SCI. 1308, 1310 (1999). See also K.F. Gensheimer et al., Preparing for Pandemic Influenza: The Need for Enhanced Surveillance, 5 EMERGING INFECTIOUS DISEASES 297, 297 (1999) ("Because it establishes the scientific foundation for a public health response, surveillance is the single most important tool for identifying new or re-emerging infectious diseases with potential to cause serious public health problems."). 
xenotransplantation, scientists would be handicapped in detecting and isolating the infectious microbes causing any resulting illness. Such a handicap could prove to be fatal because until doctors identify the illnesscausing microbes, treatment strategies may be no more sophisticated than a game of trial and error.

\section{B. Enforcing Public Safety Measures}

Although the scientific community almost universally agrees that public health safeguards must be a prerequisite to the introduction of clinical xenotransplantation, and although extensive work has gone into the development of comprehensive safeguards, little thought has been given to how to enforce these safeguards. The relevant scientific literature often appears to assume that the law will be able to accommodate and enforce whatever measures scientists deem necessary. ${ }^{38}$ The reality is that there are limits to the enforcement measures that the law can currently accommodate.

The remaining sections of this Article discuss whether officials could use existing or novel legal frameworks to enforce the proposed public safety measures. Possibilities among existing law include consent law, the law of contracts, and existing public health legislation. Because the law is not immutable, it can be adapted to reflect changing social and scientific realities. Thus, even if the public safety measures prove unenforceable under existing law, legislatures could enact new statutes or executive agencies could adopt new regulations that would render lawful the required enforcement mechanisms.

Regardless of the approved legal standards, the judiciary could declare these new enactments illegal if they transgress constitutionally protected rights and freedoms. If the courts strike down such legislation on constitutional grounds, xenotransplant recipients in the relevant jurisdiction would not be legally obligated to comply with the public health safeguards. As a result, the ability of scientists to gather epidemiological data in that jurisdiction, and hence the capacity of the public safety measures to perform their protective function, would depend entirely on the willingness of recipients to comply voluntarily with the invasive measures. In the absence of such willingness, the surveillance system would crumble, leaving society defenseless in the advent of an epidemic. Part III of this Article examines the constitutional limitations that courts might impose on public safety legislation.

38. See, e.g., Michele L. Pearson, M.D. et al., Xenotransplantation: Is the Future Upon Us?, 19 INFECTION CONTROL AND HOSP. EPIDEMIOLOGY (1998). Other scientific articles recognize that enforcement may be an issue but defer discussion of enforcement to other commentators. See, e.g., Bach et al., supra note 8, at 144. 


\section{From Informed Consent to Binding Contract?}

a) Informed Consent is Not a Promise to Undertake Future Obligations

Mandatory compliance with public safety measures has rarely, if ever, served as a prerequisite to having access to innovative medical interventions. Indeed, the case of xenotransplantation would be exceptional in this regard; all that is normally required before doctors provide medical treatment is the patient's informed consent. ${ }^{39}$ Lawmakers designed informed consent to correct the imbalance in knowledge, and hence power, between health care providers and patients. ${ }^{40}$ It is premised on the patient's right to self-determination ${ }^{41}$ and requires the physician to disclose "the nature of the proposed operation, its gravity, any material risks and any special or unusual risks attendant upon the performance of the operation." ${ }^{22}$ The level of disclosure required varies depending on the nature of the intervention. ${ }^{43}$ In the case of experimental procedures such as xenotransplantation, the degree of disclosure would be higher than that necessary for conventional medical treatments. ${ }^{44}$

In addition to the right to know, the patient's right to selfdetermination encompasses the right to accept or reject treatment. ${ }^{45}$ It is ultimately the patient, and not the health care provider, who decides whether or not the intervention will be performed. Moreover, health care providers cannot interfere with the patient's decision to refuse treatment, no matter how foolish or medically unsound they believe it to be. ${ }^{46}$

39. Ellen T. Picard \& Gerald B. Robertson, Legal liability of Doctors AND HOSPITALS IN CANADA 84-85 (3d ed. 1996).

40. Dow Corning Corp. v. Hollis, [1995] 4 S.C.R. 634, 656 ("The doctrine of 'informed consent' was developed as a judicial attempt to redress the inequality of information that characterizes a doctor-patient relationship.").

41. For an early source making reference to this right, see Schloendorff v. Soc'y of N.Y. Hosps., 105 N.E. 92, 93 (N.Y. Ct. App. 1914) ("Every human being of adult years and sound mind has a right to determine what shall be done with his own body."). See generally Tom L. Beauchamp, Informed Consent, in MEDICAL ETHICS 185-208 (Robert M. Veatch ed., 1997).

42. Hopp v. Lepp, [1980] 2 S.C.R. 192, 210. See also Canterbury v. Spence, 464 F.2d 772 (D.C. Cir. 1972); Salgo v. Leland Stanford Jr. Univ. Bd. of Trs., 317 P.2d 170 (1957); Reibl v. Hughes, [1980] 2 S.C.R. 880.

43. Margaret A. Somerville, Structuring the Issues in Informed Consent, $26 \mathrm{MCGRL}$ L.J. 740 (1981).

44. Weiss v. Solomon, [1989] 48 C.C.L.T. 280, 282 (Que. S.C.); Halushka v. Univ. of Sask., [1965] 53 D.L.R. (2d) 436, 443-44 (Sask. C.A.).

45. Hopp, 2 S.C.R. at 192.

46. See Fleming v. Reid, [1991] 4 O.R. (3d) 74, 85 (C.A.): 
Although the doctrine of informed consent protects the patient's right to know the risks of a medical procedure, it does not bind the patient to a contractual agreement. Importantly, consent speaks not to the patient's promise to undertake future obligations in consideration of having access to medical care, but to the patient's initial acquiescence to a particular intervention. In the case of xenotransplantation, the recipient's consent to the intervention, even with full understanding of the accompanying public health safeguards, would not legally bind the recipient to comply with the safeguards. This is because the recipient's right to self-determination continues after she gives her initial consent and begins treatment. Recipients could withdraw their consent, written or otherwise, at any time. ${ }^{47}$

Because the recipient's consent is insufficient to guarantee adherence to public safety measures, some other legal mechanism is required. This alternative mechanism will necessarily conflict with the now-entrenched patient autonomy model of medical decision making. As such, officials would need to find a distinct source of legal authority that might be used to trump or pre-empt the application of the right to self-determination. What we must therefore determine is the nature of the legal authority that might accomplish this task.

\section{b) Contract Law Is Not a Viable Enforcement Mechanism}

Medical commentators have emphasized that the law of contracts may provide a means of legally enforcing a patient's compliance with the safeguards. For instance, according to one commentator, "[t]he fact that the patient is going to be required to comply with postoperative monitoring alters the nature of 'consent' to something more binding and contrac-

The fact that serious risks or consequences may result from a refusal of medical treatment does not vitiate the right of medical selfdetermination. The doctrine of informed consent ensures the freedom of individuals to make choices about their medical care. It is the patient, not the doctor, who ultimately must decide if treatment-any treatment--is to be administered.

See also Walker v. Region 2 Hospital Corp., [1994] 116 D.L.R. (4th) 477 (N.B.C.A.); Malette v. Shulman, [1990] 67 D.L.R. (4th) 321 (Ont. C.A.).

47. See Ciarlariello v. Schacter, [1993] 2 S.C.R. 119, 136 (holding that a "patient's right to bodily integrity provides the basis for the withdrawal of a consent to a medical procedure even while it is underway."). The right to withdraw consent exists even in the context of life sustaining interventions. See Cruzan v. Dir., Miss. Dept. of Health, 497 U.S. 261 (1990) (holding that vegetative patient's wishes to not have life sustaining interventions must be honored if they are proven with clear and convincing evidence); Nancy B v. Hotel-Dieu de Québec, [1992] 86 D.L.R. (4th) 385 (Que. S.C.). 
tual." ${ }^{, 48}$ According to another commentator, recipients and their close contacts:

would not only have to agree to the risks attendant to a transplant procedure, but also to a contract binding the patient and others to carry out future obligations, including the patient's possible quarantine, as well as modification of the guarantees of confidentiality and surrender of the right to 'drop out' of the study. ${ }^{49}$

As currently formulated, the law of contracts would most likely be unable to ensure that recipients comply with the public health safeguards. At first blush, one might employ the common law theories of promise ${ }^{50}$ or reliance $^{51}$ to validate the contract. The theory here would be that since the recipient promises to comply with the safeguards and society relies upon that promise, society should be able to enforce the promise. Indeed, one might view compliance with the safeguards as the consideration that is required in order to have access to the innovative biotechnology. Similarly, under the Civil Code of Quebec, all that is theoretically required for the existence of a valid contract is a meeting of the minds between persons having the capacity to contract. ${ }^{52}$ Yet, there are a number of reasons for believing that the law of contracts would be incapable of serving as an effective source of legal enforcement.

There are two threshold challenges to using the law of contracts as a source of legal authority. One must first identify the legal entity with

48. A.S. Daar, Ethics of Xenotransplantation: Animal Issues, Consent, and Likely Transformation of Transplant Ethics, 21 WORLD J. SURGERY 975, 977 (1997). See also A.S. Daar, Animal-to-Human Organ Transplantation-A Solution or a New Problem?, 77 BULL. WORLD HEALTH ORG. 54, 58 (1999).

49. Bach et al., supra note 8, at 144. See also DAVID K.C. COOPER \& ROBERT P. lanZa, Xeno: The Promise of Transplanting AnImal ORgans Into Humans 218 (2000):

What is being envisaged is no longer a simple matter of the patient's signing a consent form after being provided with the necessary information. In view of the perceived potential risk to the community from infection passed from the patient to his or her contacts, the patient will be expected to enter into what can be considered a 'contract' with the surgical team and transplant center. Some have suggested that this might have to be a binding legal contract. The patient-and possibly even members of the patient's family-will agree to lifelong monitoring in return for the potential benefits that might result from undergoing the xenotransplant.

50. See generally ChARLES FRIED, CONTRACTS AS PROMISE (1981).

51. See generally P.S. ATTYAH, THE RISE AND FALl OF FREEDOM OF CONTRACT (1979).

52. See Arts. 1378, 1385 C.C.Q. (Can.). 
whom the recipients would be contracting and determine whether that entity would have the legal capacity to enter into and enforce such contractual undertakings. Stated differently, who would be the creditor of the recipient's obligation of complying with the safeguards? The surgical team or institution performing the operation? The federal or provincial/state government(s)? Society? Moreover, could any of these "creditors" enforce the obligation?

Assuming that one could answer these threshold queries, a court could nevertheless strike down the contract, or at least render it unenforceable, as being against public policy. ${ }^{53}$ Compulsory compliance with the safeguards would require the relinquishment of certain civil liberties, and, as a matter of public policy or human rights, it is highly unlikely that these could be contracted away. ${ }^{54}$ Recipients may initially agree to bind themselves to contracts calling for, among other things, the periodic provision of bodily samples. If they later withdraw their consent, however, the specific performance of these contracts would be incompatible with legislation upholding civil liberties such as the inviolability of the body. ${ }^{55}$ To be lawful, an invasion of civil liberties would have to be expressly authorized by legislation and the legislation would itself be subject to constitutional scrutiny.

Even after surmounting these hurdles, courts could nonetheless consider the contracts to be illicit. This is true because, unlike most contracts, under which there is no requirement that the debtor personally perform the obligation(s), ${ }^{56}$ the nature of the contractual undertaking in the case of xenotransplantation requires the recipient to comply with the safeguards himself or herself.

The civil law of Quebec refers to such contracts as intuitu personae and generally refuses to enforce them. ${ }^{57}$ Simply put, enforcement of such

53. See RESTATEMENT (SECOND) OF CONTRACTS $§ 178$ (1981).

54. See, e.g., Arts. 3(2), 8 C.C.Q. (Can.).

55. See, e.g., Arts. 3(1), 10 C.C.Q. (Can.); see also Quebec Charter of Human Rights and Freedoms, R.S.Q., ch. C-12, § 1, pmbl. (1985) (Can.). The specific performance of these contracts would also engage constitutional protections such as the rights to liberty and security of the person. See CAN. CoNST. (Constitution Act 1982), pt. I (Canadian Charter of Rights and Freedoms), cl. 11 \& ; see also U.S. CONST. amend. XIII (outlawing involuntary servitude).

56. In general, the debtor of the obligation(s) under a contract always has the option of delegating the performance of the obligations to a third party such as an agent or an employee.

57. Specific performance of the contract can be enforced so long as there is no requirement that the contract's prestation be carried out by the debtor in person. See Rosa- 
contracts would lead to a conflict between two competing legal valuesthose of holding the debtor to her word, and respect for individual liberty. ${ }^{58}$ In light of this conflict, the State may not use its power to force the debtor personally to execute the contract's obligations. ${ }^{59}$

In the common law, the remedy of specific performance best approximates the idea behind intuitu personae contracts. The traditional rule has been that equitable relief clauses, requiring the specific performance of contractual obligations, will only be awarded when monetary damages are inadequate. ${ }^{60}$ Such is the case where the contractual obligation involves the transfer of a "unique" parcel of land. ${ }^{61}$ Given that the viability of the public health safeguards depend on the execution of the contractual undertakings by the recipients personally, the circumstances of xenotransplantation arguably present another occasion where a court may consider monetary damages inadequate. Yet, similarly to Quebec civil law, Canadian ${ }^{62}$ and American ${ }^{63}$ common law seldom enforce the specific performance of personal service contracts.

It is also unlikely that the law of contracts could furnish an alternative remedy to specific performance, such as monetary damages that might be

lie Jukier, The Emergence of Specific Performance as a Major Remedy in Quebec Law, 47 REVUE DU BARREAU 47 (1987).

58. JEAN-LOUIS BAUdOUIN, LES OBLIGATIONS 413 (4th ed. 1993):

L'exécution en nature d'une obligation de faire, par le débiteur luimême, pose clairement le conflit entre deux principes juridiques fondamentaux: le respect de la parole donnée, qui exige que la loi fasse tout pour obliger le débiteur à l'exécution, et le respect de la liberté individuelle, selon lequel la loi ne doit pas, dans des circonstances ordinaires, aller jusqu'à priver de sa liberté celui qui ne respecte pas son engagement.

59. Id.

60. See Harnett v. Yielding, [1805] 2 Sch. \& Lef. 549, 553; see also George $\mathrm{T}$. Washington, Damages in Contract at Common Law, 47 L.Q. REV. 345 (1931).

61. Semelhago v. Paramadevan, [1996] 2 S.C.R. 415, 424-25.

62. See Warner Bros. Pictures Inc. v. Nelson, [1937] 1 K.B. 209; Emerald Resources Ltd. v. Sterling Oil Props. Mgmt. Ltd., [1969] 3 D.L.R. (3d) 630, 647 (Alta. C.A.) ("An example of a contract of which the Court will not compel specific performance is a contract of personal service .... [T] public policy; that it would be improper to make one man serve another against his will."), aff'd, [1970] 15 D.L.R. (3d) 256 (S.C.C.). See generally, ROBERT J. SHARPE, INJUNCTIONS AND SPECIFIC PERFORMANCE 7.540-7.630 (2000) (looseleaf ed.).

63. See Fitzpatrick v. Michael, 9A.2d 639 (Md. 1939); American Broadcasting Companies, Inc. v. Warner Wolf, 420 N.E.2d 363 (N.Y. Ct. App. 1981). Judicial compulsion of performance may even run afoul of the Thirteenth Amendment to the United States Constitution that prohibits involuntary servitude. See Arthur v. Oakes, 63 F. 310 , 318 (7th Cir. 1894). 
used indirectly to coerce the recipient into compliance. This is because the most logical creditor of the obligation (the surgical team or transplant center) would suffer no loss as a result of a breach of contract. The loss would instead be borne by the public, the third-party beneficiary to the contract. Yet, the public similarly would be incapable of obtaining an award in damages following a breach of contract. The common laws of the United States ${ }^{64}$ and Canada, ${ }^{65}$ as well as the civil law of Quebec, ${ }^{66}$ require that one could identify third-party beneficiaries at the time the promise is to be performed. The 'public,' however, is not an identifiable beneficiary. As a result, the most vital safeguard-the collection and archiving of bodily samples from recipients for epidemiological purposes-would remain unenforceable under contract law. ${ }^{67}$

\section{Current Public Health Legislation}

a) Current Public Health Legislation is Designed to Curb the Spread of Infectious Disease by Authorizing Examination of Individuals and Penalties for Non-compliance

The federal governments of both the United States and Canada have enacted legislation designed to curb the spread of communicable disease. ${ }^{68}$ While the American federal government, acting primarily through the Centers for Disease Control and Prevention, ${ }^{69}$ has been active in commu-

64. E. Allan FARNSWORTH, CONTRACTS $§ 10.3$ (3rd ed. 1999).

65. In common law Canada, the doctrine of privity has not been relaxed to the extent that it has in other jurisdictions such as Quebec and the United States. As a result, third-party beneficiaries can only derive rights from a contract in very narrow circumstances. See Fraser River Pile \& Dredge v. Can-Dive Servs. Ltd., [1999] 3 S.C.R. 108; London Drugs Ltd. v. Nagel Int'l Ltd., [1992] 3 S.C.R. 299. The public would not be recognized as a third-party beneficiary in common law Canada.

66. Arts. 1444-1445 C.C.Q. (Can.).

67. Even if this third party beneficiary problem were solved, the courts could construe any damages specified in a contract with a xenotransplant recipient as punitive penalties rather than liquidated damages. Such categorization would render such measures unenforceable, however, as it is a fundamental precept of contract law that damages for breach of contract must be an estimation of actual damages resulting from the breach, not a coercive mechanism to obtain performance. See RESTATEMENT (SECOND) OF CONTRACTS $\$ 356$ (1981). The same rule applies in Canada. See G.H.L. FRIDMAN, THE LAW OF CONTRACT IN CANADA 81 1-17(4th ed. 1999).

68. See, e.g., 42 U.S.C. $§ 264$ (1994) (U.S. Public Health Service Authority); 21 C.F.R. $\$ 1240$ (2001) (U.S. Food and Drug Administration Authority); Quarantine Act, R.S.C., ch. Q-1 (2000) (Can.).

69. The Centers for Disease Control and Prevention is an agency of the United States Department of Health and Human Services. For a description of the U.S. Centers for Disease Control's active role in public health matters, see Centers for Disease Control 
nicable disease control, the Canadian federal government's participation has largely been limited to the management of communicable disease in the context of people crossing the Canadian border. ${ }^{70}$

In addition to this central regulation through their federal governments, each U.S. state ${ }^{71}$ as well as every Canadian province and territory ${ }^{72}$ has enacted public health legislation specifically addressing communicable disease control. In Canada, although some provinces such as British Columbia and Saskatchewan have enacted specific venereal disease legislation, ${ }^{73}$ most provinces deal with all communicable diseases by way of a single statute. ${ }^{74}$ In the United States, the public health laws of most states are much more disease specific. ${ }^{75}$ For instance, in addition to having a number of provisions that apply to communicable diseases generally, New York's public health law also has separate provisions dealing specifically with typhoid fever, poliomyelitis, tuberculosis, HIV, and others.

In both the United States and Canada, public health legislation affords wide powers to public health officials. These include the powers to examine, detain, and isolate individuals, and to enter and close places. ${ }^{77}$ Given that the collection and archiving of bodily samples is vital to effective post-xenotransplantation surveillance, the most significant power con-

and Prevention, About CDC, at http://www.cdc.gov/aboutCDC.htm (last modified July 28, 2001).

70. See Immigration Act, R.S.C., ch. I-2, § 91 (2000) (Can.); Quarantine Act, R.S.C., ch. Q-1 (2000) (Can.).

71. See, e.g., DEL. CODE ANN. tit. $16 \S 501-508$ (2001); D.C. CODE ANN. § 6-117 (1999); KAN. STAT. ANN. §65-118 (2000); KAN. STAT. ANN. §§ 65-116(a)-(m), 119, $122,123,126-129$ (1992).

72. Public Health Act, R.S.A. 1984, ch. P-27.1 (2001) (Can.); Public Health Act, R.S.M., ch. P210 (2001) (Can.); Health Protection and Promotion Act, R.S.O. 1990, ch. H-7 (2001) (Can.).

73. See Venereal Disease Act, R.S.B.C. 1996, ch. 475 (2001) (Can.); Venereal Disease Prevention Act, R.S.S. 1978, ch. V-4 (2000) (Can.).

74. See Public Health Act, R.S.A. 1984, ch. P-27.1 (2001) (Can.); Public Health Act, R.S.M., ch. P210 (2001) (Can.); Health Protection and Promotion Act, R.S.O. 1990, ch. H-7 (2001) (Can.).

75. See, e.g., Colo. Rev. STAT. § 25-4-1201 (2000) (streptococcus); Del. CODE ANN. tit. $16 \S 507$ (2001) (diphtheria immunization); FLA. STAT. $\$ 392.51$ (2000) (tuberculosis); MD. CODE ANN. HEALTH-GEN. I \& 18-324 (2001) (tuberculosis).

76. N.Y. PUB. Health LAW $\S 2120$ (McKinney 2001) (typhoid fever); N.Y. PUB. HEALTH LAW $\$ 2164$ (poliomyelitis, mumps, vaccinations); N.Y. PUB. HEALTH LAW $\S 2200$ (McKinney 2001) (tuberculosis); N.Y. PUB. HEALTH LAW $§ 2781$ (McKinney 2001) (HIV testing).

77. See, e.g., DEL. CODE ANN. tit. $16 \$ \$ 501-508$ (2001); MD. CODE ANN. HEALTHGEN. I § 18-324 (2001); Public Health Act, R.S.A. 1984, ch. P-27.1 §§ 30, 39, 40 (2001) (Can.); Health Protection and Promotion Act, R.S.O. 1990, ch. H-7 § 22(4) (2001) (Can.). 
tained in public health legislation will be the authority to examine individuals. The nature and extent of the power to examine, however, varies from jurisdiction to jurisdiction. In the province of Ontario, for example, the medical officer of health can direct a person-under the authority of the Health Protection and Promotion Act-to submit "to an examination by a physician." ${ }^{78}$ Unfortunately, because the Act does not define the term "examination," it is unclear whether this includes the power to collect bodily specimens.

The legislation in Quebec, although equally ambiguous, appears to grant relatively broad powers of examination. ${ }^{79}$ The legislation specifies that the Minister of Health and Social Services has the duty to "establish and maintain a system for gathering ... medical and epidemiological data $\ldots .{ }^{80}$ Further, the provincial government, in consultation with the $\mathrm{Bu}$ reau of Quebec Physicians, has the authority to "take the steps necessary" to examine persons coming under the jurisdiction of the relevant act. ${ }^{81}$ Similarly, the California Health and Safety Code authorizes the State Department of Health, upon being informed by a health officer of any contagious, infectious, or communicable disease, to "take measures as are necessary to ascertain the nature of the disease and prevent its spread." ${ }^{, 82}$ If the language of necessity in the Quebec and California statutes is meant to authorize a particular mode of examination so long as it can qualify as "necessary" to the determination of whether an individual is infected with a communicable disease, then these laws could be used to sanction the collection of bodily specimens. ${ }^{83}$

Some legislation, however, unambiguously provides for the collection of bodily samples. For instance, British Columbia's legislation specifically authorizes the collection of "blood, sputum or other excreta" and the per-

78. Health Protection and Promotion Act, R.S.O. 1990, ch. H.7, § 22(4)(f) (2001) (Can.).

79. See Public Health Protection Act, R.S.Q. 1977, ch. P-35 (2001) (Can.).

80. Id. $\S 2(\mathrm{~d})$.

81. Id. $\S \S 10,11$.

82. Cal. Health \& SAFETy CODE $\S 120,140$ (West 2000). See also id. $\S 120,175$.

83. Alberta's public health legislation also uses the language of necessity and, although equally as broad, is somewhat less vague than the legislation in Quebec and California. The Alberta legislation would almost certainly authorize the collection of bodily specimens since it provides that individuals coming under the purview of the Act must "submit to any examinations necessary to determine whether the person is infected with the disease." Public Health Act, R.S.A. 1984, ch. P-27.1, § 41 (2001) (Can.) (emphasis added). 
formance of X-ray examinations. ${ }^{84}$ Likewise, New York's public health law provides that the commissioner of health can set forth in the sanitary code of the state of New York "the diseases for which specimens shall be submitted for examination to a laboratory approved by the department." 85

In sum, the power to collect bodily samples for the purposes of examination probably exists in most jurisdictions. While the legislation in some jurisdictions expressly and unambiguously provides for the collection of bodily specimens, the legislation in other jurisdictions uses language that is sufficiently broad to infer the existence of the power to take samples.

On balance, public health law provides a more satisfactory legal mechanism to enforce xenotransplantation precautions than contract law. Unlike the law of contracts, public health law encompasses the authority to demand the performance of human conduct that officials deem necessary to protect society from the spread of infectious diseases. ${ }^{86}$ Moreover, the enforcement provisions of public health legislation have greater coercive effect than those of contract law since courts can levy severe penalties for non-compliance with an order given pursuant to legislation. The nature and extent of these penalties vary greatly among jurisdictions. For instance, although every jurisdiction empowers officials to impose a monetary fine in the case of non-compliance, the maximum fine that they can issue varies greatly. ${ }^{87}$ In addition, while the legislation in some jurisdictions provides only for the imposition of monetary fines, ${ }^{88}$ the legislation

84. Health Act, R.S.B.C. 1996, ch. 179, § 65(3) (2001) (Can.). Similarly, Saskatchewan_public health legislation authorizes the taking of "specimens of blood or body discharge." Venereal Disease Prevention Act, R.S.S. 1978, ch. V-4, § 15(2) (2000) (Can.).

85. N.Y. PUB. HEALTH LAW $\S 225(5)(\mathrm{g})$ (McKinney 2001). See also id. § 201 (requiring the New York state department of health to "conduct laboratory examinations for the diagnosis and control of disease"); id. $\$ 2100$ (requiring local boards of health to exercise "proper and vigilant medical examination and control of all persons ... infected with or exposed to [communicable diseases].").

86. See supra note 77 and accompanying text.

87. In Quebec, public health law authorizes the imposition of monetary fines up to a maximum of $\$ 1000$ for each day that the offense continues. Public Health Protection Act, R.S.Q. 1977, ch. P-35, $\$ 71$ (2001) (Can.). In Ontario, the maximum is $\$ 5000$ for each day or part day that the offense continues. Health Protection and Promotion Act, R.S.O. 1990, ch. H.7, § 101(1) (2001) (Can.). In contrast to these elevated penalties, Alberta's legislation provides for a fine of not more than $\$ 100$ for each day that the offense continues. Public Health Act, R.S.A. 1984, ch. P-27.1, § 81(2) (2001) (Can.).

88. See, e.g., id. 
in other jurisdictions also permits the temporary incarceration of noncompliant individuals. $^{89}$

In short, current public health legislation may offer a source of legal authority from which to guarantee compliance with postxenotransplantation public safety measures. Unlike contract law, existing public health legislation in some jurisdictions can require the performance of conduct such as the collection of bodily specimens. In addition, because of its strong enforcement provisions, public health law has coercive tools that contract law does not. What remains to be determined, however, is whether there are any impediments that might frustrate or disqualify the use of current public health legislation as a means of regulating xenotransplantation.

b) Current Public Health Legislation is Nevertheless Incapable of Adequately Regulating Xenotransplantation

One possible impediment to the use of current public health legislation is the common law right to self-determination. This right grants individuals the authority to accept, reject and/or withdraw their consent to medical treatments. The right to self-determination may not, however, hinder the application and enforcement of public health legislation, because statutes take precedence over such common law doctrines. Moreover, should a separate statute protect the right to self-determination, as it does in Ontario, ${ }^{90}$ the public health legislation typically pre-empts the application of a conflicting statute. ${ }^{91}$

Nevertheless, there are a number of other reasons why current public health legislation cannot regulate xenotransplantation. One reason is that in the case of xenotransplantation, officials probably could not satisfy the legislation's conditions precedent. Typical conditions include the presence of a certain level of proof that the individual in question has in fact contracted an infectious disease and poses a risk to the public health. In Quebec, for example, officials have the power to examine only a "person who apparently has a disease" contemplated by the legislation. ${ }^{92}$ In Ontario, officials must have "reasonable and probable" grounds for believing that a

89. In New York, violations of the sanitary code can result in both monetary penalties as well as imprisonment. A first offense is punishable by a fine not exceeding $\$ 250$ or by imprisonment for a time not exceeding 15 days, or both. N.Y. PUB. HEALTH LAW $\S 229$ (McKinney 2001). A subsequent offense is punishable by a fine not exceeding $\$ 500$ or by imprisonment for a time not exceeding 15 days, or both. Id.

90. See Health Care Consent Act, S.O. 1996, ch. 2 (2001) (Can.).

91. See, e.g., Health Protection and Promotion Act, R.S.O. 1990, ch. H-7, §22(5.1) (2001) (Can.).

92. Public Health Protection Act, R.S.Q. 1977, ch. P-35 § 11 (2001) (Can.). 
communicable disease "exists or may exist or that there is an immediate risk of an outbreak"; that the disease "presents a risk to the health of persons"; and that "the requirements specified in the order are necessary in order to decrease or eliminate the risk to health presented by the communicable disease." 93

In general, satisfaction of the required level of proof will depend on the extent to which an individual appears to be sick. Thus, if an individual exhibits symptoms of infection officials may have grounds for invoking the legislation. In contrast, if an individual is asymptomatic officials will normally not have prima facie grounds justifying the application of the intrusive legislation. There are, however, exceptions to this general rule. Tuberculosis legislation in California provides one such exception. The legislation allows officials to examine those who are in close contact with individuals infected with active tuberculosis and anyone else officials have "reasonable grounds to determine are at heightened risk of tuberculosis exposure." 94 Such exceptions are present only in legislation that applies only to specific diseases and are therefore not generally applicable.

Because the infectious disease risks associated with xenotransplantation, even if foreseeable, are theoretical both in nature and in severity, there would probably be insufficient grounds for invoking and applying general public health law provisions to recipients for as long as they remained asymptomatic. ${ }^{95}$ Yet, the viability of a post-xenotransplantation surveillance system depends upon its ability to collect epidemiological data whether the recipients appear to be symptomatic or not. Similarly, existing public health legislation would be inapplicable to xenotransplantation because it applies only to infectious diseases that legislators can list in the legislation or corresponding regulations. For instance, New York's officials can only enforce their public health legislation against individuals infected by or exposed to a communicable disease that the sanitary code expressly designates. ${ }^{96}$

93. Health Protection and Promotion Act, R.S.O. 1990, ch. H.7, \& 22(2) (2001) (Can.).

94. Cal. Health \& SAFETy CODE $\S 120,142$ (West 2000). See also id. $\S \S 121,363$, 121,364 .

95. As one group of commentators put it: "existing legislation would require modification in order to compel the continued surveillance of asymptomatic individuals. In general, Canadian public health laws are designed to allow a response when an individual has a known infectious disease. There are no 'monitoring' provisions." Florencio \& Caulfield, supra note 8 , at 283.

96. N.Y. PUB. HEALTH LAW $\S 2100$ (McKinney 2001). Similarly, Ontario's public health legislation only applies to communicable and virulent diseases, the former being defined as "a disease specified as a communicable disease by regulation made by the 
The degree of specificity that the application of public health legislation currently requires is unattainable for xenotransplantation. Commentators have described xenotransplantation as presenting an unquantifiable yet undeniable risk to the public health. ${ }^{97}$ The risk is undeniable because our science base enables us to appreciate the theoretical threats associated with xenotransplantation. More importantly, the risk remains unquantifiable because we have a limited ability to predict the nature and extent of the harms that might arise. Scientists have already discovered the identity of one potential disease threat that is capable of replicating in human cells in vitro ${ }^{98}$ and in mice in vivo, ${ }^{99}$ but does not appear to lead to illness in recipients. ${ }^{100}$ There could exist countless other infectious agents residing in xenografts that have not yet been identified. These infectious agents could cause disease in their natural state or could recombine with innocuous human retroviruses to form new chimeric agents. ${ }^{101}$ It is unclear which infectious agents present in xenografts would be communicable and pathogenic in human populations. ${ }^{102}$

Minister" and the later being defined as including those illnesses enumerated in the legislation such as ebola, plague, Lassa fever, leprosy, smallpox, syphilis, and tuberculosis as well as any diseases specified by regulation. See Health Protection and Promotion Act, R.S.O. 1990, ch. H.7, § 1(1) (2001) (Can.).

97. See Chapman et al., supra note 6. See generally supra notes 6-8 and accompanying text.

98. Paul Le Tissier et al., Two Sets of Human-Tropic Pig Retrovirus, 389 NATURE 681 (1997);..Ulrich Martin et al., Expression of Pig Endogenous Retrovirus by Primary Porcine Endothelial Cells and Infection of Human Cells, 352 LANCET 692 (1998); Clive Patience et al., Infection of Human Cells by an Endogenous Retrovirus of Pigs, 3 NATURE MED. 282 (1997).

99. Luc J.W. van der Laan et al., Infection by Porcine Endogenous Retrovirus After Islet Xenotransplantation in SCID Mice, 407 NATURE 501 (2000).

100. Walid Heneine et al., No Evidence of Infection with Porcine Endogenous Retrovirus in Recipients of Porcine Islet-Cell Xenografts, 352 LANCET 695 (1998); Khazal Paradis et al., Search for Cross-Species Transmission of Porcine Endogenous Retrovirus in Patients Treated with Living Pig Tissue, 285 SCIENCE 1236 (1999).

101. Jon Allan, Silk Purse or Sow's Ear, 3 NATURE MED. 275 (1997); Douglas M. Smith, Endogenous Retrovirus in Xenografts, 328 NEw ENG. J. MED. 142 (1993). Such recombination is a course of events not uncommon in cells infected with retroviruses. M.A. McClure et al., Sequence Comparisons of Retrovirai Proteins: Relative Rates of Change and General Phylogeny, 85 PROC. NAT'L ACAD. SCI. U.S.A. 2469 (1988). This latter mechanism is thought to account for the pandemics caused by the modified influenza viruses in 1957 (subtype H2N2) and 1968 (subtype H3N2). C. Scholtissek et al., On the Origin of the Human Influenza Virus Subtypes H2N2 and H3N2, 87 VIROLOGY 13 (1978).

102. Although some agents might not be pathogenic, others, like the deadly human influenza virus which in 1918 is estimated to have killed between 20 to 40 million people in less than a year, might result in considerable morbidity and mortality. See Elizabeth 
In sum, current public health law provisions cannot be used to enforce post-xenotransplantation surveillance because the nature and communicability of the pathogen and severity of the resultant disease are not yet determined. Furthermore, most current public health legislation would fail because symptoms or other indices of disease are required before official intervention, even though adequate prevention of epidemics relies on the ability to identify infected but asymptomatic individuals. This is problematic given that public health law has the unique ability to enforce performance of human conduct such as the collection of bodily specimens. It is this ability that renders public health law the most effective, if not the only, legal mechanism for ensuring compliance with the public safety measures.

There are, however, two solutions that may allow officials to apply public health legislation to xenotransplantation. Officials could either amend the general provisions in public health legislation so that they apply to xenotransplantation, or enact xenotransplantation-specific legislation. The latter represents the better solution because existing general public health provisions are ill-suited to cope with the exceptional difficulties posed by xenotransplantation, and because amendment to incorporate the necessary powers might overtax and confuse these provisions.

\section{Proposal for New Xenotransplantation Legislation}

The main function of xenotransplantation legislation would be to provide legal authority for the monitoring requirements of the public health safeguards-especially the periodic collection of bodily specimens from recipients regardless of whether or not they appear to be symptomatic, and the power to conduct post-mortem analyses. In this regard, the legislation would only apply to those individuals who undergo an animal-to-human organ, tissue, or cellxenotransplantation procedure. Pre-xenotransplanta tion baseline sampling would not fall under the aegis of the legislation but would instead be a prerequisite to undergoing the operation. In addition to authorizing monitoring of recipients, xenotransplantation legislation could provide a contingency plan in the event that recipients become infected with communicable agents as a result of the operation. If so, the legislation would need to grant public health officials the powers to treat and to detain and isolate the recipient if necessary. Alternatively, control of any emerging communicable illnesses, once detected through surveillance authorized by xenotransplantation-specific legislation, could be handled by existing public health legislation.

Pennisi, Virology: First Genes Isolated From the Deadly 1918 Flu Virus, 275 SCIENCE 1739 (1997). 
If enacted, the monitoring provisions of xenotransplantation legislation would grant health authorities greater power than that found in existing public health legislation. In existing legislation, the officials' power to examine functions only to assess whether an individual is infected with a specific and identifiable agent. Such an examination will normally lead to treatment or other intervention only if the examination results are positive. In the case of xenotransplantation monitoring provisions, however, the officials' power to examine must be expanded because monitoring will need to be an ongoing process as opposed to a single event. This is necessary to monitor recipients for signs of infection and to collect epidemiological data because those carrying out the monitoring will be looking not for a specific agent but for any and all signs of infection that might arise over time. Ongoing monitoring will also be critical for the identification of novel infectious agents through epidemiological strategies that require large data bases, as well as data points collected at different moments in time.

In implementing xenotransplantation legislation, officials must also consider the appropriate penalties for violations of the monitoring provisions. In general, loss of liberty would be too onerous an enforcement mechanism to impose on recipients given the theoretical nature of the risks to the public health. As long as recipients remain asymptomatic and there is no evidence of further transmissibility, officials would not have sufficient grounds to justify imprisonment. If diligently enforced, monetary fines could be a sufficiently persuasive means of enforcement. Officials should, however, ultimately be empowered to isolate and detain individuals to prevent or quell the spread of disease should recipients become infected with a communicable agent posing a threat to the public health. Officials need to direct more thought toward devising the fairest enforcement model possible in light of the current social and scientific knowledge that has been gathered on xenotransplantation.

Another issue requiring further reflection is what level of government should have the power to enact and enforce the legislation. To be most effective, the public health safeguards would need to be uniformly applicable worldwide. Assuming that global implementation will not be feasible in the near future due to the novelty of the issue, uncertainty of the potential harm, and disparities in governmental and economic resources available to implement public health measures, legislation should at least extend to the largest areas with border controls-typically nations. ${ }^{103}$ If it is

103. In areas such as the European Union with no national border controls, implementation across the included territory would be advisable. 
not, then recipients receiving a xenotransplant in a jurisdiction with adequate safeguards could move to a jurisdiction having less onerous and possibly substandard safeguards. Such a state of affairs would erode the surveillance system and would therefore be unacceptable.

There are two ways of ensuring legislative uniformity within national borders. Legislators could prepare a single set of minimum safeguards that would be ratified at the local level by each of the provinces/states in every nation hosting clinical xenotransplantation. Another possibility would be to have the central governments of each nation enact the legislation. Although this latter option would pose little problem in countries where the federal government has played an active role in communicable disease control (for example, the United States), ${ }^{104}$ it may pose problems in other countries. where the involvement of the central government in public health matters has thus far been limited (for example, Canada) ${ }^{105}$ Nevertheless, the problem is likely solvable given the national scope of the potential health problem. ${ }^{106}$

Although xenotransplantation legislation would impose onerous obligations on recipients, it nevertheless represents a fair compromise between outright prohibition of clinical xenotransplantation and unduly jeopardizing the public's health through non-existent, inadequate or ineffective regulation. In exchange for the opportunity to save and prolong their lives, xenotransplant recipients would provide society with the minimum level of epidemiological data that it requires to protect itself. When comparing the advantages of xenotransplantation with the disadvantages of the public

104. See Lawrence O. Gostin, Public Health Law in a New Century-Part II: Public Health Powers and Limits, 283 JAMA 2979, 2979-80 (2000). In addition to direct intervention through the U.S. Centers for Disease Control and other divisions of the U.S. Department of Health and Human Services, the federal government often uses its constitutional spending power to make crucial federal public health funds contingent on state conformance with uniform federal standards. See id. at 2980.

105. See supra, note 70 and accompanying text.

106. For example, given its dual jurisdiction over matters of health, the Canadian parliament likely possesses the authority to enact xenotransplantation legislation:

Legislation dealing with health matters has been found within the provincial power where the approach in the legislation is to an aspect of health, local in nature .... On the other hand, federal legislation in relation to 'health' can be supported where the dimension of the problem is national rather than local in nature .... In sum 'health' is not a matter which is subject to specific constitutional assignment but instead is an amorphous topic which can be addressed by valid federal or provincial legislation, depending in the circumstances of each case on the nature or scope of the health problem in question.

Schneider v. The Queen, [1982] 2 S.C.R. 112, 141-142. 
health legislation, the advantage of saving one's life through xenotransplantation should greatly outweigh the drawback of having to provide periodic serum samples. Moreover, in light of the public health risks associated with xenotransplantation, the monitoring provisions would not represent an excessive safety measure. Rather, they would be a minimum precaution based on sound scientific principles. Thus, judicial review of xenotransplantation legislation should be reluctant to dismiss the scientific underpinnings upon which it is founded. ${ }^{107}$

\section{CONSTITUTIONAL DIMENSION: BALANCING THE RIGHTS OF THE COLLECTIVE AND THE DUTY OF THE STATE TO PROTECT THE PUBLIC HEALTH WITH THE RIGHTS OF THE INDIVIDUAL}

The use of coercive measures such as monetary fines to attain public health goals raises difficult issues concerning an individual's responsibility to protect other members of society as well as society's obligation to respect the civil rights and liberties of its individual citizens. ${ }^{108}$ Should

107. Lawrence O. Gostin, Public Health Law in a New Century-Part III: Public Health Regulation: A Systematic Evaluation, 283 JAMA 3118, 3120 (2000):

[T]o the extent possible, risk assessments should be based on objective and reliable scientific evidence provided by the multiple disciplines of public health, including medicine, virology, bacteriology, and epidemiology. Science-based risk assessments provide a more secure ground for decision making and avoid reflexive actions based on irrational fears, speculation, stereotypes, or pernicious mythologies.

See also Lawrence O. Gostin, The Future of Public Health Law, 12 AM. J. LAw \& MED. 461, 464 (1988) [hereinafter Gostin, The Future of Public Health Law]:

Science has a more precise understanding of the etiological agents of infectious disease, the most likely harborers of the agent, the most efficient modes of its transmission, and the methods of modifying behaviors or environments in order to interrupt its spread. Accordingly, modern measures for reducing the spread of disease are predominantly based upon research, education, and counselling, specifically targeted to groups at risk of spreading or contracting the disease. Public health statutes and judicial review of public health action should reflect these new scientific understandings by requiring that the goals of public health measures be limited to the interruption of the most efficient modes of disease transmission.

108. As stated by one commentator:

[T]here is a fundamental conflict of interest between providing medical care to individuals and providing public health services to a community. The patient-autonomy model that underlies personal health care is incompatible with the subrogation of individual interests that is neces- 
xenotransplantation legislation be enacted and subsequently challenged, ${ }^{109}$ courts will be seized with the delicate task of striking the right balance between individual and societal rights and responsibilities. The purpose of this section is not to provide an exhaustive discussion of the constitutional dimension of the problem but simply to offer some preliminary thoughts on some of the issues that are likely to be raised.

\section{A. Individual Rights and Freedoms}

\section{Personal Rights and Liberties}

Section 7 of the Canadian Charter guarantees an individual's right not to be deprived of life, liberty, or security of the person except in accordance with the principles of fundamental justice. ${ }^{110}$ Xenotransplantation safeguards do not, however, involve literal intrusion upon the physical integrity of nonconsenting recipients since the monitoring provisions would provide for monetary sanctions, rather than physical force, as a means of enforcing the collection of bodily samples. This is important because physical intrusion would clearly violate the Charter's provisions. ${ }^{111}$ Notwithstanding the non-physical nature of the coercion involved, xenotransplantation legislation could infringe a transplant recipient's constitutional rights. For instance, the legislation would infringe the recipient's right to personal autonomy and self-determination by removing the option of withdrawing his or her participation from public health safeguards ${ }^{12}$ Ad-

sary for effective public health ... . Public health rejects the patient's right to have sole control of his/her treatment.

Edward P. Richards \& Katharine C. Rathbun, The Role of the Police Power in 21st Century Public Health, 26 SEXUALly TRANSMTTTED DISEASES 350, 354-55 (1999).

109. Florencio \& Caulfield, supra note 8 , at 284 ("Although xenotransplant candidates would have to agree to participate in all public health measures to be eligible for the transplant procedure, once the procedure has taken place and their health has improved, patients may feel that the restrictions on their rights are too onerous.").

110. Can. Const. (Constitution Act 1982), pt. I (Canadian Charter of Rights and Freedoms), cl. $11 \S 7$.

111. CAN. CONST. (Constitution Act 1982), pt. I (Canadian Charter of Rights and Freedoms), cl. $11 \S 7-8$. If an individual is symptomatic, he will be isolated and detained in accordance with regular public health legislation and thus, there would be no violation of the Charter's provisions.

112. The right to autonomy derives from the common law but it is arguably also protected by the Charter. See Rodriguez v. B.C.(A.G.), [1993] 3 S.C.R. 519, 588:

There is no question, then, that personal autonomy, at least with respect to the right to make choices concerning one's own body, control over one's physical and psychological integrity, and basic human dignity are encompassed within security of the person, at least to the extent of freedom from criminal prohibitions which interfere with these. 
ditionally, by tying weighty penal consequences to non-compliant behavior, the legislation might also be contravening the recipient's interest in personal security by inflicting serious psychological stress upon him. ${ }^{113}$ Determining the viability of xenotransplantation legislation under section 7 of the Charter would involve a two-step process. First, a court would decide if there had been a breach of the right to life, liberty or security of the person. If there was no breach, the legislation would be upheld as valid. If there was a breach, a court would next determine whether such a breach was in accordance with the principles of fundamental justice.

The Supreme Court of Canada has been using two different approaches to determine whether fundamental justice justifies a violation of personal rights and liberties. According to the first approach, the contravention of an individual's section 7 rights will be in accordance with the principles of fundamental justice so long as the societal or state interest outweighs the individual's right to life, liberty and/or security of the person. ${ }^{114}$ The second approach is to perform an analysis under section 1 of

Given the quasi-criminal and penal nature of public health legislation, it is highly probable that the right to personal autonomy would enjoy as much protection in a public health context as it does in a criminal context. See also Fleming v. Reid, [1991] 4 O.R. (3d) 74, 88 (C.A.) ("[T] he common law right to determine what shall be done with one's own body and the constitutional right to security of the person, both of which are founded on the belief in the dignity and autonomy of each individual, can be treated as coextensive.").

113. See R. v. Morgentaler, [1988] 1 S.C.R. 30, 56 ("[S]tate interference with bodily integrity and serious state-imposed psychological stress, at least in the criminal law context, constitutes a breach of security of the person."). It is noteworthy that the minority in Morgentaler chose to set forth a more stringent test as to when state-imposed psychological stress would result in a violation of the security of the person interest:

As to an asserted right to be free from any state interference with bodily integrity and serious state-imposed psychological stress, I would say that to be accepted, as a constitutional right, it would have to be based on something more than the mere imposition, by the State, of such stress and anxiety .... A breach of the right would have to be based upon an infringement of some interest which would be of such nature and such importance as to warrant constitutional protection. This, it would seem to me, would be limited to cases where the state-action complained of, in addition to imposing stress and strain, also infringed another right, freedom or interest which was deserving of protection under the concept of security of the person.

Id. at 146-147. Interestingly, because the monitoring provisions would both impinge upon the personal autonomy of recipients and impose psychological stress upon them, counsel for the recipients might contend that even the requirements of the minority's test would be satisfied in the circumstances.

114. See, e.g., Thomson Newspapers v. Canada (Dir. of Investigation and Research, Restrictive Trade Practices Comm'n), [1990] 1 S.C.R. 425, 583 ("Fundamental justice in 
the Charter which states that the rights and freedoms guaranteed by the Charter are subject to "such reasonable limits prescribed by law as can be demonstrably justified in a free and democratic society."115 This Article argues that the second approach would be superior to the first in determining whether xenotransplantation legislation is justified by the principles of fundamental justice.

The first approach, or the 'balancing' approach, to fundamental justice is problematic in several regards. First, courts consider the societal interest under section 7, where the burden of proof lies with the Charter claimant, instead of under section 1, where the burden of proof lies with the state. Second, unlike section 1, section 7 does not provide an analytical framework capable of structuring judicial discretion during the performance of the balancing test. Third, the fact that courts consider the interests of the state along with those of the individual directly within section 7 of the Charter weakens the ability of the Charter to operate as a rights-based, counter-majoritarian instrument. ${ }^{116}$

The second approach defines the principles of fundamental justice as being located within the basic tenets of the Canadian legal system. ${ }^{17}$ Under this approach, courts only consider the interests of the state under section 1 of the Charter. ${ }^{118}$ This second approach does not suffer from the

our Canadian legal tradition ... is primarily designed to ensure that a fair balance be struck between the interests of society and those of its citizens"); see also R. v. Beare, [1988] 2 S.C.R. 387, 415 (holding that fingerprinting a person charged with but not convicted of an indictable offense does not infringe upon rights guaranteed in section 7 of the Canadian Charter of Rights and Freedoms); R. v. Lyons, [1987] 2 S.C.R. 309 (examining whether the dangerous offenders provisions of the criminal code contravened the right to liberty guaranteed under the Charter); R v. Jones, [1986] 2 S.C.R. 284 (balancing the compelling state interest in compulsory education against right to liberty under Section 7 of the Charter).

115. Can. Const. (Constitution Act 1982), pt. I (Canadian Charter of Rights and Freedoms), cl. $11 \S 1$.

116. See Patrik S. Florencio \& Robert H. Keller, End-of-Life Decision Making: Rethinking the Principles of Fundamental Justice in the Context of Emerging Empirical Data, 7 HEALTH L. J. 233, 247 (1999).

117. See Reference Re Section 94(2) of the Motor Vehicle Act, R.S.B.C. 1979, [1985] 2 S.C.R. 486, 503 ("The principles of fundamental justice are to be found in the basic tenets of our legal system. They do not lie in the realm of general public policy but in the inherent domain of the judiciary as guardian of the justice system.").

118. For example, legislation depriving individuals of life, liberty, and security of the person must not be substantively or procedurally arbitrary lest it violate the principles of fundamental justice. See B.(R.) v. Children's Aid Soc'y of Metro. Toronto, [1995] 1 S.C.R. 315, 374 ("The protection of a child's right to life and to health, when it becomes necessary to do so, is a basic tenet of our legal system, and legislation to that end accords with the principles of fundamental justice ...."); R. v. Swain, [1991] 1 S.C.R. 933, 977 
infirmities enumerated above and is hence both analytically superior and more just in its result than its balancing counterpart. ${ }^{119}$

According to either the first or the second approach, however, the xenotransplantation legislation meets the requirements of fundamental justice, although the second approach requires that the legislation meet a stricter test. Indeed, given that the monitoring provisions would not be arbitrary-they would be based on sound scientific principles for the legitimate objective of protecting the public health and would apply only to individuals having received a xenotransplantation-officials could forcefully maintain that the legislation would not be in violation of the principles of fundamental justice. Thus, notwithstanding the breaches to the personal security interest of recipients, the monitoring legislation would not contravene section 7 of the Charter since the breaches would be in accordance with fundamental justice.

The U.S. Constitution also limits the extent to which public health legislation may impinge upon the fundamental rights of privacy and bodily integrity. The concept of privacy is most directly embodied in the Fourth Amendment to the Constitution, which provides that the government shall not violate " $[t]$ he right of the people to be secure in their persons, houses, papers, and effects, against unreasonable searches and seizures ...."120 The Supreme Court has consistently held that state-compelled collection and testing of bodily fluids such as blood or urine, such as would be required of xenotransplant recipients, is a "search" subject to the Fourth Amendment. ${ }^{121}$ Whether a search or seizure passes constitutional scrutiny under the Fourth Amendment would depend upon whether that search or seizure is reasonable in light of the balance between the intrusion on the

(holding that the "common law rule which allows the Crown to raise evidence of insanity over and above the accused's wishes is a denial of liberty which is not in accordance with the principles of fundamental justice"); Singh v. Minister of Employment and Immigration, [1985] 1 S.C.R. 177, 220 (holding that procedures under the 1976 Immigration Act did not meet the requirements of fundamental justice under section 7 of the Charter and that such procedures did not constitute a reasonable limit on the rights of persons claiming refugee status within the meaning of section 1 of the Charter).

119. See Florencio \& Keller, supra note 116 , at $247-248$, for a more detailed discussion of why the second approach is superior to the first approach.

120. U.S. CONST. amend. IV.

121. See, e.g., Vernonia School District 47J v. Acton, 515 U.S. 646, 652 (1995); Skinner v. Railway Labor Executives' Ass'n, 489 U.S. 602, 617 (1989); Schmerber v. Cal., 384 U.S. 757, 767-68 (1966). Courts would consider a search that is authorized or required by xenotransplantation legislation to be state-compelled even if private transplant centers or physicians conduct it. See Skinner, 489 U.S. at 614-15. Courts may also view sampling of bodily fluids as a "seizure" because it interferes with a xenotransplant recipient's possessory interest in her bodily fluids. See id. at 617, n.4. 
individual's legitimate privacy interests and the government's legitimate interest in protecting the public health. ${ }^{122}$

Courts are likely to find that the intrusion on a transplant recipient's privacy is minimal for several reasons. First, a reasonable expectation of the privacy of her bodily fluids is substantially reduced because ongoing surveillance of those bodily fluids would follow a recipient's voluntary and extensive experience with the high degree of intrusion involved in transplant surgery and the large number of related medical examinations that are conducted before and after surgery. ${ }^{123}$ Second, several factors would make the character of the intrusion less compromising of privacy. Two such factors are that officials would likely take blood samples rather than excretory fluids ${ }^{124}$ and that officials would draw these samples in a medical establishment rather than in a more public setting. ${ }^{125} \mathrm{~A}$ final consideration which should inform the drafting of xenotransplantation legislation, is that courts will be more likely to consider a search or seizure reasonable if the results are disclosed only to those who need to know the results-i.e., the recipient's physicians and relevant public health authorities. $^{126}$

Privacy and bodily integrity are also protected by the "substantive due process" conception of implied fundamental liberty rights embodied in the Due Process Clause of the Fourteenth Amendment. ${ }^{127}$ Courts generally

122. See Vernonia, 515 U.S. at 652-53. Although we believe that the risks posed by xenotransplantation without surveillance make the government's interest in surveillance compelling, the U.S. Supreme Court requires only that the governmental interest be more important than the legitimate expectation of privacy that testing would intrude upon. See $i d$. at 660-61. However, it is particularly important that the governmental interest in surveillance clearly outweighs the privacy interest because xenotransplant recipients would be tested without individual suspicion of infection. See Skinner, 489 U.S. at 624 (holding that a search may be reasonable despite the absence of individualized suspicion if the - important governmental interest furthered by the search would be jeopardized by a requirement of individualized suspicion).

123. See Vernonia, 515 U.S. at 656-57 (holding that student athletes have a reduced expectation of privacy because they voluntarily "go out for the team" and because public school students already are subject to medical examination and vaccination).

124. See Skinner, 489 U.S. at 617,626 (distinguishing blood tests from urinalysis and other tests taken in a manner that compromises traditional expectations of privacy).

125. See Schmerber, 384 U.S. at 771 (holding that blood tests are more reasonable when taken by a physician in a hospital environment according to accepted medical practices).

126. See Vernonia, 796 F. Supp. at 1364.

127. See, e.g., Cruzan v. Dir., Miss. Dept. of Health, 497 U.S. 261, 262 (1990) (discussing the right to bodily integrity); Roe v. Wade, 410 U.S. 113, 153 (1973) (recognizing that the right to privacy encompasses the abortion decision); Eisenstadt v. Baird, 405 U.S. 438,438 (1972) (recognizing a fundamental right to privacy including the decision 
subject laws that burden a fundamental right to "strict scrutiny." 128 Under strict scrutiny, when an individual's liberty interest is balanced against the government's interest in enforcing a restriction on liberty, the restriction must be narrowly drawn to achieve a compelling state interest, rather than merely having a rational relation to a governmental interest.

Even if we assume that a court would apply strict scrutiny, xenotransplantation legislation is likely to pass constitutional muster. For decades the Supreme Court has been highly deferential to the government with respect to public health legislation, rarely questioning its compelling nature. ${ }^{129}$ This is particularly true when legislation calls for intrusions of limited duration and severity, ${ }^{130}$ and when it protects the health of the individual whose rights are being intruded upon, as well as the rights of the populace. ${ }^{131}$ Although monitoring of a xenotransplant recipient could go on for an indefinite duration, perhaps for many years, the severity of the intrusions necessary for surveillance should be minimal and the health of the recipient is protected by such surveillance. Thus, carefully drawn xenotransplantation legislation should withstand a substantive due process challenge.

\section{Finding the Right Balance}

This section has argued that although the monitoring provisions in xenotransplantation legislation would constitute a violation of the rights of recipients to liberty and/or to the security of their persons, this violation would be in accordance with the principles of fundamental justice and therefore inherently justified. Lest this reasoning be amiss, it is also important to inquire whether the proposed legislation might be justified on

whether or not to use contraception). But see, Bowers v. Hardwick, 478 U.S. 186, 191 (1986) (failing to extend the right of privacy to acts of sodomy). The Fourteenth Amendment provides that no state shall "deprive any person of life, liberty, or property, without due process of law." U.S. CONST. amend. XIV.

128. See, e.g., Planned Parenthood of Southeastern Pa. v. Casey, 505 U.S. 833, 871 (1992).

129. See, e.g., Washington v. Harper, 494 U.S. 210, 222 (1990) (finding that forced treatment of a prisoner with antipsychotic medication was justified by potential harm to the prisoner and others); Whalen v. Roe, 429 U.S. 589, 603-604 (1977) (upholding prescription reporting legislation for controlled substances); Buck v. Bell, 274 U.S. 200, 207 (1927) (allowing sexual sterilization of a mentally retarded prisoner on public health grounds); Jacobson v. Mass., 197 U.S. 11, 31 (1905) (upholding compulsory vaccination of the general public).

130. See, e.g., Jacobson, 197 U.S. at 24-30.

131. See, e.g., id.; Washington, 494 U.S. at 222. 
the less fundamental ground that it imposes reasonable limitations that can be demonstrably justified in a free and democratic society. ${ }^{132}$

In his book "The Plague," Camus expressed the idea that the consequences of an epidemic are not experienced by citizens individually, but by society as a whole in the form of a collective history. ${ }^{133}$ It is exactly this characteristic-the collective nature of the health ramifications that can result from infectious diseases-that makes public health legislation so important. Public health law seeks to reduce the incidence of morbidity and mortality by preventing or curbing the spread of infectious diseases. Society has long considered the protection and preservation of the public health to be a value of fundamental importance and this sentiment persists to this day. ${ }^{134}$ The state would clearly have a compelling interest in enforcing a surveillance system that aims to acquire epidemiological data that would permit health authorities rapidly to identify and contain infectious agents that could arise from xenotransplantation.

Yet, even when the state sets out to accomplish an important end point, the means by which it attempts to do so must be rationally related to the purpose of the legislation. In the case of public health legislation, the

132. The answer to this question should inform any constitutional analysis of xenotransplantation legislation, but is specifically required under section 1 of the Charter. See CAN. CONST. (Constitution Act 1982), pt. I (Canadian Charter of Rights and Freedoms), cl. $11 \S 1$. For the leading case on balancing under section 1 of the Charter, see R. v. Oakes, [1986] 1 S.C.R. 103.

133. See Albert Camus, The Plague 167 (Stuart Gilbert trans., Vintage Int'l 1991):

Thus week by week the prisoners of plague put up what fight they could. Some ... even contrived to fancy they were still behaving as free men and had the power of choice. But actually it would have been truer to say that by this time ... the plague had swallowed up everything and everyone. No longer were there individual destinies; only a collective destiny, made of plague and the emotions shared by all.

134. See, Gostin, The Future of Public Health Law, supra note 107, at 483:

Ultimately, the right of the state to take measures which avoid a probable and grave harm must be respected, even at the cost of individual civil liberties. It does no service to groups at risk for disease to fail to implement effective public health measures in the name of protection of their liberty. The health of the community is perhaps the most important human and societal value.

The Latin maxim salus populi suprema lex, meaning that the welfare or health of the people is the supreme law of the land, frequently appeared in nineteenth century cases such as Haverty v. Bass, 66 Me. 71 (1876). See WILLIAM J. NOVAK, THE PEOPLE'S WELFARE: LAW AND REGULATION IN NINETEENTH-CENTURY AMERICA (1996). See also Elmer E. Smead, Sic utere tuo ut alienum non laedas: A Basis of the State Police Power, 21 CORNELL L.Q. 276 (1936). 
means, or the specific powers that the legislation grants, must be premised on the biological characteristics of the particular infectious disease threats from which the legislation seeks to shield society. For instance, although restrictions on the rights to liberty and association may be a valid policy in the case of airborne pathogens, they are not justified in the case of bloodborne pathogens such as HIV, whose transmissibility is limited to activities such as blood transfusions, sexual relations and/or needle-sharing. ${ }^{135}$

The biological reality of xenotransplantation is that animal agents residing in xenografts could infect xenotransplant recipients who could then pass the agents to the community at large. Although this infectious disease threat is foreseeable, the identity of the agents that are likely to infect recipients as a result of xenotransplantation, and the method of their transmission, remain unknown. Given this reality, the government's implementation of a surveillance system to collect data that will hopefully enable scientists to identify and track down infectious agents that might arise as a result of xenobiotechnology is unquestionably a rational means of protecting the public health. Moreover, requiring xenotransplant recipients to engage in conforming behavior would be central to the state's interest in having an effective surveillance system given that "[i]ncomplete and unreliable data [would] greatly reduce our power to detect and contain outbreaks of infectious disease." 136

Such a surveillance system would also constitute the most equitable means of protecting the public health from the infectious disease risks associated with xenotransplantation. The government could take other approaches to fulfill this important objective such as isolating recipients or forbidding clinical xenotransplantations until more is known about the infectious disease risks. These approaches would be better suited to the task of protecting the public health but would involve far greater restrictions to the liberty and security interests of recipients. A surveillance system has the distinct advantage of offering an important means of protecting the public health while allowing recipients both to take advantage of xenobiotechnology and to retain their freedoms of movement and association within society. Thus, a surveillance system represents the best of the possible options.

It is important, however, not to make light of the fact that xenotransplantation legislation - by authorizing the periodic examination of asymptomatic xenotransplant recipients-would grant health authorities greater

135. L.O. Gostin, The Resurgent Tuberculosis Epidemic in the Era of AIDS: Reflections on Public Health, Law, and Society, 54 MARYLAND L. REV. 1, 8 (1995).

136. Florencio \& Caulfield, supra note 8, at 284. 
power than that provided by traditional public health legislation. It would, in other words, represent an extensive change to our existing law and would need to be rigorously justified by public policy. Policy matters involving extensive changes to the existing law are better left, in a constitutional democracy, to the legislative branch of government. ${ }^{137}$ Correspondingly, when asked to review legislative solutions to complex matters of policy, the judiciary should extend to the legislature a sufficient degree of deference. ${ }^{138}$ This is especially true when the policy matter relates to the protection of the public health. ${ }^{139}$ If a court struck down xenotransplanta-

137. See, e.g., Dobson (Litig. Guardian of) v. Dobson, [1999] 2 S.C.R. 753, 766 ("Matters of public policy are concerned with sensitive issues that involve far-reaching and unpredictable implications for Canadian society. It follows that the legislature is the more appropriate forum for the consideration of such problems and the implementation of legislative solutions to them."); see also Winnipeg Child and Family Servs. v. G.(D.F.), [1997] 3 S.C.R. 925, 960-961 (holding that it is not appropriate for a court to extend its power to order the detention of a pregnant woman for the purpose of preventing harm to her unborn child); Watkins v. Olafson, [1989] 2 S.C.R. 750, 764 (holding that in the absence of enabling legislation or the consent of all parties, a court cannot order that a plaintiff forego his traditional right to a lump-sum judgment for a series of period payments).

138. See, e.g., McKinney v. Univ. of Guelph, [1990] 3 S.C.R. 229, 315 :

$[\mathrm{H}]$ aving accepted the importance of the legislative objective, one must ... recognize that if the legislative goal is to be achieved, it will inevitably be achieved to the detriment of some. Moreover, attempts to protect the rights of one group will also inevitably impose burdens on the rights of other groups. There is no perfect scenario in which the rights of all can be equally protected.

See also Irwin Toy Ltd. v. Quebec (A.G.), [1989] 1 S.C.R. 927, 933 (sustaining the reasonableness of a legislative conclusion that a "ban on commercial advertising directed to children was the minimal impairment of free expression consistent with the pressing and substantial goal of protecting children against manipulation through advertising"); R. v. Edwards Books and Art, [1986] 2 S.C.R. 713, 787 (upholding the constitutionality of the Retail Business Holidays Act based on the stated legislative purpose). American case law also expresses the view that a degree of deference must be extended to the legislature. See, e.g., Williams v. Mayor of Baltimore, 289 U.S. 36, 42 (1933) ("The judicial function is exhausted with the discovery that the relation between means and end is not wholly vain and fanciful, an illusory pretense. Within the field where men of reason may reasonably differ, the legislature must have its way.").

139. See supra note 129; see also Arizona ex rel. Conway v. Southern Pac. Co., 145 P.2d 530, 532 (Ariz. 1943) ("where the police power is set in motion in its proper sphere, the courts have no jurisdiction to stay the arm of the legislative branch") (quoting State v. Superior Court, 174 P.973, 976 (Wash. 1918).). See generally Lawrence O. Gostin, The Americans with Disabilities Act and the Corpus of AntiDiscimination Law: A Force for Change in the Future of Public Health Regulation, 3 HEALTH MATRIX 89 (1993) (arguing that the standard judicial review of the constitutionality of public health statutes is being replaced by disability law which is applicable to protect people with infectious conditions). 
tion legislation on constitutional grounds, the capacity of the surveillance system to generate the data required for the protection of the public health would depend entirely on the willingness of recipients voluntarily to comply with the safeguards. In the absence of such willingness, the surveillance system would collapse and society could be left defenseless in the wake of an epidemic.

\section{B. Freedom From Discrimination}

Since xenotransplantation legislation would only apply to individuals who underwent a xenotransplant operation, one might ask whether the legislation violates section 15 of the Charter by infringing an individual's right to be free from discrimination. ${ }^{140}$ In Law v. Canada (Minister of Employment and Immigration), the Supreme Court of Canada recently restated the appropriate approach to conducting equality analyses. ${ }^{141}$ The Court stated that a court making a discrimination inquiry should make the following inquiries:

First, does the impugned law (a) draw a formal distinction between the claimant and others on the basis of one or more personal characteristics, or (b) fail to take into account the claimant's already disadvantaged position within Canadian society. ...? Second, was the claimant subject to differential treatment on the basis of one or more of the enumerated and analogous grounds? And third, does the differential treatment discriminate in a substantive sense, bringing into play the purpose of $s .15(1)$ of the Charter in remedying such ills as prejudice, stereotyping, and historical disadvantage ? $^{142}$

A court making the above inquiry would not hold that xenotransplantation violates an individual's right to be free from discrimination. Xenotransplantation legislation would draw a formal distinction on the basis of whether or not individuals are recipents of animal cells, tissues and/or organs and would impose the burden of complying with the public health safeguards upon those who are recipients. This distinction, however, would not be based on an enumerated or analogous ground. ${ }^{143}$ More-

140. CAN. CONST. (Constitution Act 1982), pt. I (Canadian Charter of Rights and Freedoms), cl. $11 \S 15$.

141. See Law v. Canada (Minister of Employment and Immigration), [1999] 1 S.C.R. $497,524$.

142. Id.

143. Some may argue that xenotransplantation legislation would distinguish individuals on the basis of physical disability which is an enumerated ground. Yet, the mere fact of having undergone a xenotransplantation and consequently of being a carrier of 
over, even if one could persuasively argue that the legislation did distinguish on the basis of an enumerated or analogous ground, the legislation would not be discriminatory because it would not be based on stereotyping, historical disadvantage, or political and social prejudice in Canadian society. It would be based, rather, on sound scientific principles and the need to safeguard the health of society.

The corresponding analysis under the Equal Protection Clause of the Fourteenth Amendment to the U.S. Constitution is similar. ${ }^{144}$ The law does not allow public health authorities to exercise their police powers in ways that discriminate based upon race or other suspect classes without a compelling state interest. ${ }^{145}$ Governmental regulation of the public health, however, would not violate the Equal Protection Clause merely because it applies only to xenotransplant recipients and is, therefore, not allencompassing. ${ }^{146}$ Xenotransplantation legislation would apply uniformly to all xenotransplant recipients and therefore would only need to be rationally related to a legitimate government interest to survive constitu-

animal cells, tissues and/or organs does not render recipients physically disabled. There is no disability per se. If it were otherwise, then all individuals having undergone some form of surgery, or at least those having undertaken an allotransplantation, would be subject to the characterization of being physically disabled and would be deserving of constitutional protection. Interestingly, Professor Hogg has contended that legislative distinctions that are based on personal characteristics arising as a result of voluntary choices, such as the choice to undergo a xenotransplantation, are not deserving of constitutional protection. See Peter W. HoGg, Constitutional LaW of Canada 914-15 (4th ed. 1996):

Another way of looking at immutability as the common element of the listed personal characteristics is to notice that the characteristics are inherent, rather than acquired. They do not reflect a voluntary choice by anyone, but rather an involuntary inheritance .... It is true that individuals may claim to be treated unfairly by the law for conditions that are their own responsibility, but this kind of claim even if fully justified does not warrant a constitutional remedy.

144. The Equal Protection Clause provides that the government may not deprive any person of life, liberty or property "without equal protection of the laws." U.S. CONST. amend. XIV.

145. See, e.g., City of Cleburne v. Cleburne Living Ctr., 473 U.S. 432, 442-46 (1985) (declining to recognize the mentally retarded as a quasi-suspect class, and suggesting similar treatment for "the disabled, the mentally ill, and the infirm"); Coolbaugh v. State of La., 136 F.3d 430, 433-34 (5th Cir. 1998) (surveying federal case law denying heightened scrutiny for various forms of physical disability); Jew Ho v. Williamson, 103 F. 10 (N.D. Cal. 1900) (striking down a bubonic plague quarantine that affected only the Chinese population).

146. See Zucht v. King, 260 U.S. 174, 176-77 (1922). 
tional scrutiny. ${ }^{147}$ In light of the sound public health rationale for enacting xenotransplantation safeguards and the lack of any history of discrimination against xenotransplant recipients, narrowly drawn xenotransplantation legislation would survive challenge under the Equal Protection Clause. ${ }^{148}$

Although some may worry that officials may enforce xenotransplantation legislation in a discriminatory manner-namely, in a manner that is influenced by social characteristics instead of in a manner that is neutral and uniform-this risk does not speak to the constitutionality of the legislation itself. Should such difficulties arise, agencies such as human rights commissions $^{149}$ and/or ombudspersons ${ }^{150}$ could remedy them. Interestingly, similar fears were raised ${ }^{151}$ when the New York City Department of Health updated its Health Code to permit compulsory actions, such as the detention for treatment of persistently non-compliant tuberculosis infected individuals. ${ }^{152}$ The anticipated discriminatory practices, however, never materialized. ${ }^{153}$ Indeed, a recent follow-up study found that the Health Code was not enforced in a discriminatory fashion since patients were detained on the basis of their history of compliance, rather than on the basis of their social characteristics. ${ }^{154}$

147. See, e.g., City of Cleburne, 473 U.S. at 442 (1985) (zoning regulations barring group home for the mentally disabled subject only to the rational basis test, not heightened scrutiny).

148. Indeed, it has been suggested that even legislation quarantining all HIV-infected individuals - a concept far more restrictive than most alternative strategies now in place to control the spread of HIV-would likely pass muster under the Equal Protection Clause. See 7 Deborah Jones Merritt, Communicable Disease and Constitutional Law: Controlling AIDS, 61 N.Y.U. LAW REV. 739 (1986).

149. See, e.g., Human Rights Code, S.O. 1993, ch. H.19 (2001) (Can.).

150. See, e.g., Ombudsman Act, R.S.O. 1990, ch. O.6 (2001) (Can.).

151. George J. Annas, Control of Tuberculosis-The Law and the Public's Health 328 NEW ENGL. J. MED. 585 (1993) (raising the concern that the tuberculosis regulations might be enforced in a discriminatory manner-i.e., that patients with a history of drug abuse or homelessness could be singled out for legal action).

152. N.Y. CITY HEALTH CODE $\$ 11.47$ (d) (1994).

153. For an excellent discussion of the legal and policy issues surrounding the tuberculosis control measures that were adopted by the New York City Department of Health, see Carlos A. Ball \& Mark Barnes, Public Health and Individual Rights: Tuberculosis Control and Detention Procedures in New York City, 12 YALE LAW \& POLICY REVIEW 38 (1994).

154. M. Rose Gasner et al., The Use of Legal Action in New York City to Ensure Treatment of Tuberculosis, 340 NEW ENGL. J. MED. 359, 365 (1999). 


\section{CONCLUSION}

Given the significant risks of harm associated with xenobiotechnology, the scientific community agrees that robust public safety measures need to accompany the introduction of clinical xenotransplantation. There is a need to devise a legally effective means of ensuring adherence to such public safety measures because a recipient's refusal to comply voluntarily with the safeguards would leave society without any means of protecting itself in the event of emerging infectious diseases. This Article has argued that xenotransplantation-specific public health legislation presents the most effective means of enacting and enforcing the appropriate public health safeguards.

Neither consent law nor the law of contracts would be capable of accomplishing this important objective. Consent law is ill suited to enforce the specific performance of promises because lawmakers designed it to serve as a mechanism of communicating the waiver of legal rights on the part of the consenting party, thereby obviating liability on the part of the party who received the consent. In the case of xenobiotechnology, the consent of recipients to the xenotransplant procedure and to its accompanying safeguards, such as the periodic collection of bodily specimens, would merely indicate the acquiescence of recipients to having the interventions performed on their person. Importantly however, the recipients' consent would not legally bind them, because they could unilaterally withdraw their consent to the public health safeguards at any time after having received the xenotransplant.

Contract law would be similarly ineffective. Because it would be essential for recipients to comply personally with the public safety measures, the law of contracts would be unable to use state power to force the personal execution of contractual obligations. Moreover, because specific performance of these contracts would be incompatible with competing legal principles, including the inviolability of the human body, an invasion of civil liberties would need to be expressly authorized by legislation.

In addition, existing public health legislation is not capable of enforcing the necessary public health safeguards. Although existing public health legislation might be amended to incorporate the powers necessary for the periodic examination of asymptomatic xenotransplant recipients, such amendments might overburden and confuse the existing statutes. The better solution would be to enact new legislation specific to the underlying science and particular risks of harm associated with xenotransplantation.

Xenotransplantation legislation would be a legally effective means of compelling compliance with the safeguards. Such legislation could require 
the performance of conforming behaviors and could authorize the issuance of monetary fines against recipients who, having benefited from the life saving intervention, refuse to honor their obligations under the legislation. Ultimately however, the ability of xenotransplantation legislation to guarantee the generation of the epidemiological data necessary to protect the public health will depend on its ability to withstand constitutional attack.

This Article has argued that the post-xenotransplantation surveillance system would survive a constitutional attack. The legislation would not be discriminatory and although the monitoring provisions of the legislation would constitute a violation of the rights of recipients to liberty and/or to the security of their person, this violation would be in accordance with the principles of fundamental justice and therefore would pass constitutional muster. If the constitutionality of the legislation ultimately depends on a court's balancing of the competing interests, the judiciary should be reluctant to dismiss the exceptional nature of the risks of harm associated with xenobiotechnology and therefore should take a deferential approach to the proposed legislative solutions. 
BERKELEY TECHNOLOGY LAW JOURNAL 